Portland State University

PDXScholar

1989

\title{
Oregon Women in Educational Administration: Profiles and an Analysis of Upward Career Mobility Factors
}

Leland D. Chapman

Portland State University

Follow this and additional works at: https://pdxscholar.library.pdx.edu/open_access_etds

Part of the Educational Administration and Supervision Commons, and the Women's Studies Commons

Let us know how access to this document benefits you.

\section{Recommended Citation}

Chapman, Leland D., "Oregon Women in Educational Administration: Profiles and an Analysis of Upward Career Mobility Factors" (1989). Dissertations and Theses. Paper 1174.

https://doi.org/10.15760/etd.1173

This Dissertation is brought to you for free and open access. It has been accepted for inclusion in Dissertations and Theses by an authorized administrator of PDXScholar. Please contact us if we can make this document more accessible: pdxscholar@pdx.edu. 


\title{
OREGON WOMEN IN EDUCATIONAL ADMINISTRATION: PROFILES AND AN ANALYSIS OF UPWARD CAREER MOBILITY FACTORS
}

by

LELAND D. CHAPMAN

A dissertation submitted in partial fulfillment of the requirements for the degree of

\author{
DOCTOR OF EDUCATION \\ in \\ EDUCATIONAL LEADERSHIP: \\ ADMINISIRATION AND SUPERVISION
}

Portland State University 
TO THE OFFICE OF GRADUATE STUDIES AND RESEARCH:

The members of the Comittee approve the dissertation of Leland D. Chapman presented November 9, 1989.

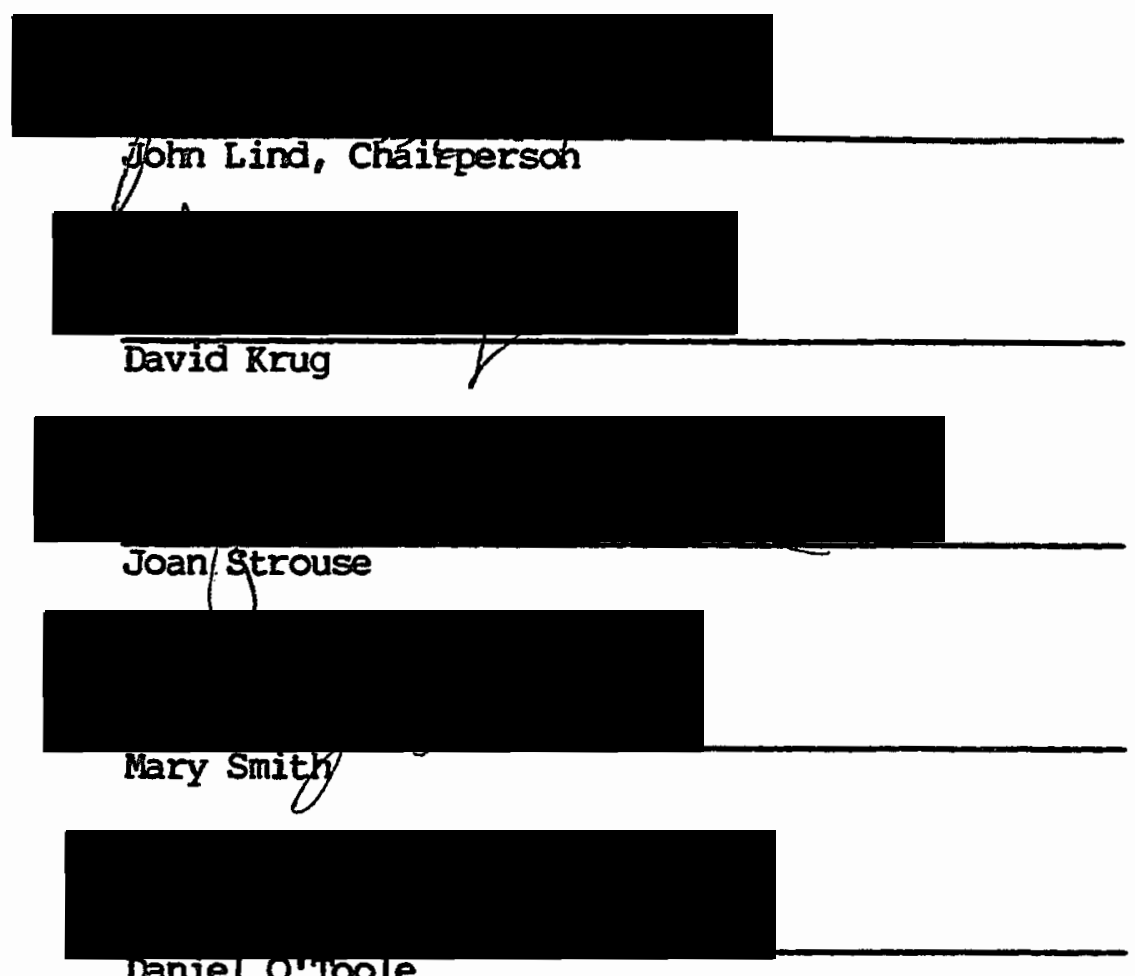

Daniel o'ioole

APPROVED:

Robert B. Everhart, Dean of the School of Ecucation

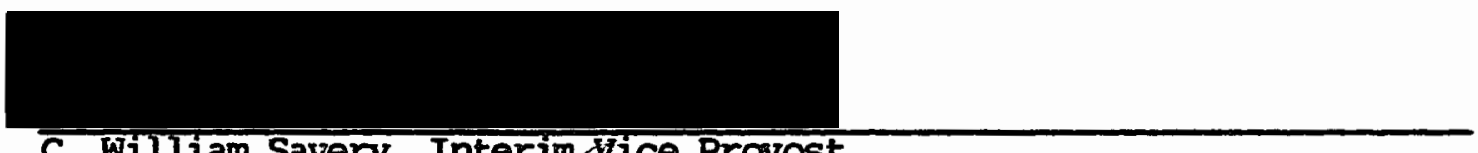

C. William Savery, Interim dice Provost

for Graduate Studies and Research 
AN ABSTRACT OF THE DISSERTATION OF Leland D. Chapman for the Doctor of Education in Ecucational Leadership presented November 9, 1989.

Title: Oregon Women in Educational Adninistration: Profiles and an Analysis of Upward Career Mobility Factors.

APPROVED BY MEMBERS OF THE DISSERTATION COMMITTEE:

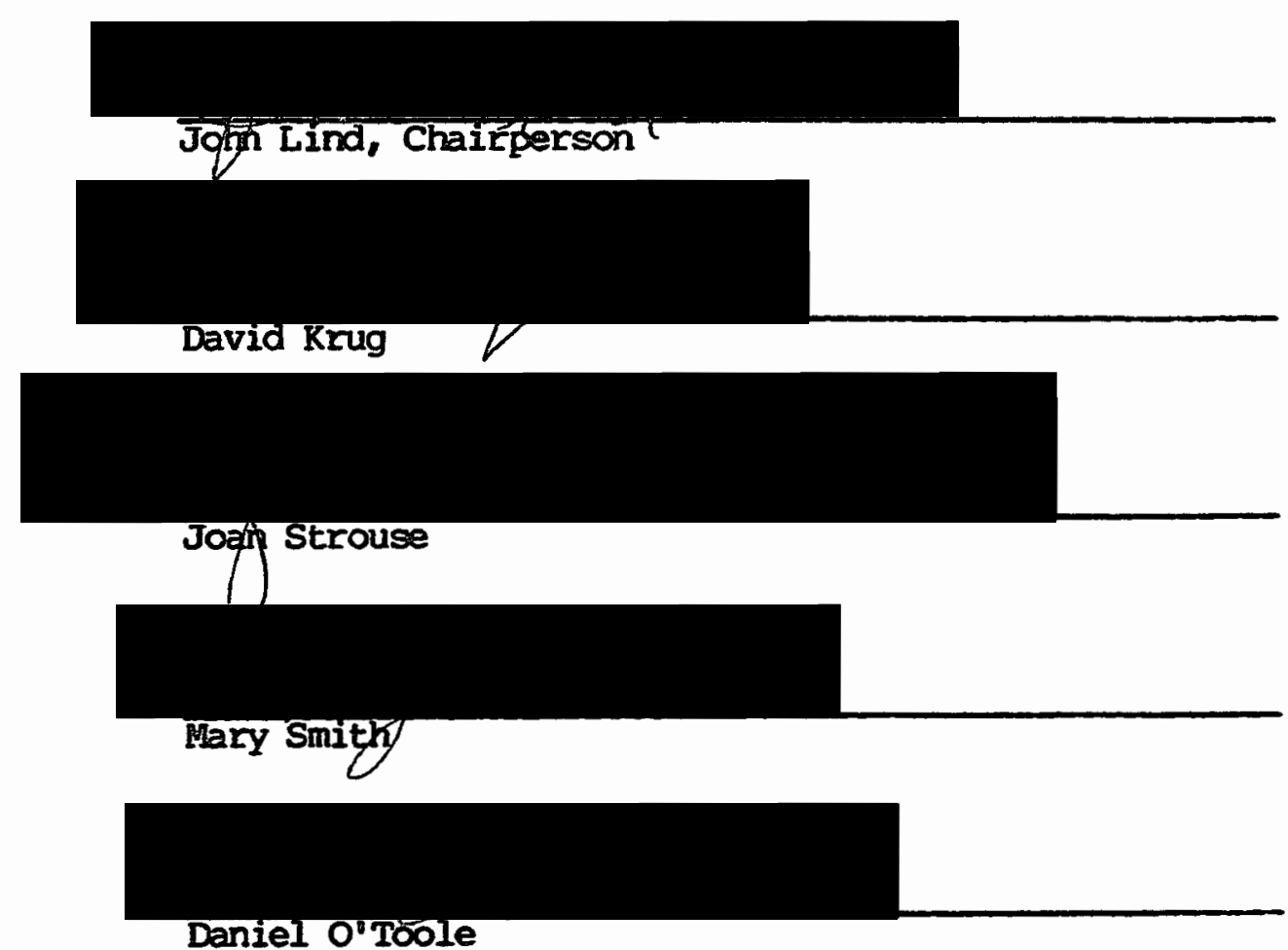

The first purpose of this study was to determine from the positive and negative factors identified by Jones and Montenegro (1982), which factors Oregon female administrators perceived had influenced upward mobility in their careers. Study of this topic reveals added information and direction to adninistrators of 
university aơninistrative programs, school board members and school personnel administrators involved in hiring and providing training or staff developrent. As a result, the commonalities and differences among iemale school acministrators in Oregon are identified. Identifying the factors that relate to upward mobility of tenured and nontenured female administrators provides insight and hopefully will promote further investigation.

A second purpose of the study was to provide, from the demographic data concerning upward career mobility of nontenured and tenured female acministrators, a profile that identifies those practices which have proven to be effective when considering career decisions in school administration.

Descriptive statistics were used to quantify the data recovered from a research instrument given to 218 female acministrators and responded to by 118 (548) of the sample population. Parametric and nonparametric tests were administered to the data collected. Analysis of the tests resulted in a written description of the similarities and/or differences between the tenured administrators' and the nontenured acministrators' perception of the factors that influenced their upward career mobility. Additionally, the demographic data were analyzed, and profiles of the two groups were developed, again to show similarities and/or differences.

The conclusions of the study supported the research hypotheses that:

(1) there is no difference between the perception of identified positive and negative factors to upward career mobility between nontenured and tenured female school acministrators, and; 
(2) there is no difference in the profile of the nontenured and the tenured female school administrator in Oregon.

A synthesis of the conclusions was made from the analysis of positive and negative career factors as well as the profiles of Oregon women school administrators which basically stated that the group of nontenured administrators is much like the group of practicing tenured administrators. Recommendations were made to women aspiring to be adninistrators for the application of the conclusions and study of identified characteristics or elements of positive and negative factors which lead to upward mobility. Profiles of the administrators were also made for use in self assessment for both groups of female adninistrators.

Suggestions for additional study were made based upon the findings and experience in conducting the study. Similar study or replication of the study is encouraged in order to provide further insight into the reasons for more women not achieving administrative positions, especially that of principal. 


\section{ACRNONLEDEYENTS}

I wish to express my sincere appreciation to my wife, Lynn, for her love, encouragement, patience, sacrifice, and forgiveness during this period of our lives. I am deeply indepted to her devotion to this cause, the welfare of our children, Toby and Travis, and to education.

I would also like to thank the members of my comittee, Dr. Joan Strouse, Dr. Dan O'Toole, Dr. Mary Smith, Dr. David Krug, and especially Dr. Jack Lind, chairperson, for their advice, time, expertise, and encouragement.

I am additionally indebted, as education should be, to the many women adninistrators that made this research possible. They are a vast, relatively untapped resource that can only enhance our profession, hopefully in the near future. 


\section{CHAPTER}

I INTRODUCTION $\ldots \ldots \ldots \ldots \ldots \ldots \ldots \ldots \ldots \ldots \ldots \ldots \ldots \ldots \ldots . \quad 1$

Statement of the Problem ................ 3

Assumptions $\ldots \ldots \ldots \ldots \ldots \ldots \ldots \ldots \ldots \ldots \ldots \ldots . \ldots \ldots$

Limitations $\ldots \ldots \ldots \ldots \ldots \ldots \ldots \ldots \ldots \ldots \ldots \ldots \ldots$

Definition of Terms $\ldots \ldots \ldots \ldots \ldots \ldots \ldots \ldots \ldots . . \ldots$

Purpose of the Study $\ldots \ldots \ldots \ldots \ldots \ldots \ldots \ldots \ldots . . .6$

Method of Investigation ................. 9

Organization of the Research .............. 9

II REVIEW OF LITERATURE $\ldots \ldots \ldots \ldots \ldots \ldots \ldots \ldots \ldots \ldots \ldots \ldots . . \ldots$

Introduction $\ldots \ldots \ldots \ldots \ldots \ldots \ldots \ldots \ldots \ldots \ldots . . \ldots \ldots$

Historical Overview .................... 11

Socialization, Legal and Cultural Influences on Women in Educational Administration .. 23

The Present Status of Women in Educational Administration $(1980-88) \ldots \ldots \ldots \ldots \ldots \ldots . . . . .30$

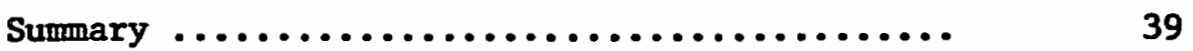

III PROCEDURES $\ldots \ldots \ldots \ldots \ldots \ldots \ldots \ldots \ldots \ldots \ldots \ldots \ldots \ldots \ldots . \ldots \ldots$

The Sample $\ldots \ldots \ldots \ldots \ldots \ldots \ldots \ldots \ldots \ldots \ldots \ldots \ldots . \ldots \ldots$

Design $\ldots \ldots \ldots \ldots \ldots \ldots \ldots \ldots \ldots \ldots \ldots \ldots \ldots \ldots . \ldots \ldots$ 
Instrumentation $\ldots \ldots \ldots \ldots \ldots \ldots \ldots \ldots \ldots \ldots . \ldots \ldots$

Hypotheses $\ldots \ldots \ldots \ldots \ldots \ldots \ldots \ldots \ldots \ldots \ldots \ldots \ldots$

Data Collection ..................... 46

Statistical Analysis ................. 48

Sumary $. \ldots \ldots \ldots \ldots \ldots \ldots \ldots \ldots \ldots \ldots \ldots \ldots \ldots . . \ldots$

IV RESEARCH FINDINGS $\ldots \ldots \ldots \ldots \ldots \ldots \ldots \ldots \ldots \ldots \ldots \ldots . . \ldots$

Introduction $\ldots \ldots \ldots \ldots \ldots \ldots \ldots \ldots \ldots \ldots \ldots \ldots$

Presentation of Data $\ldots \ldots \ldots \ldots \ldots \ldots \ldots \ldots . . . . . .6$

Description of Population Sample ........... 51

Positive Factors $\ldots \ldots \ldots \ldots \ldots \ldots \ldots \ldots \ldots \ldots$

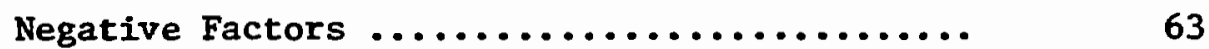

The Profile of a Nontenured Administrator .... 67

The Profile of a Tenured Administrator ....... 70

Education Level $\ldots \ldots \ldots \ldots \ldots \ldots \ldots \ldots \ldots \ldots \ldots$

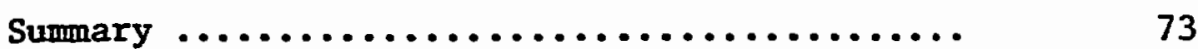

$\checkmark$ SUMMARY, DISCUSSION, AND RECOMMENDATIONS $\ldots \ldots \ldots \ldots .81$

Introduction $\ldots \ldots \ldots \ldots \ldots \ldots \ldots \ldots \ldots \ldots \ldots \ldots, \quad 81$

Summary $\ldots \ldots \ldots \ldots \ldots \ldots \ldots \ldots \ldots \ldots \ldots \ldots \ldots \ldots . \ldots . \ldots . \ldots$

The Instrumentation $\ldots \ldots \ldots \ldots \ldots \ldots \ldots \ldots \ldots . \ldots$

Discussion $\ldots \ldots \ldots \ldots \ldots \ldots \ldots \ldots \ldots \ldots \ldots \ldots \ldots$

Recommendations and Implications .......... 87

Suggestions for Future Research ........... 90

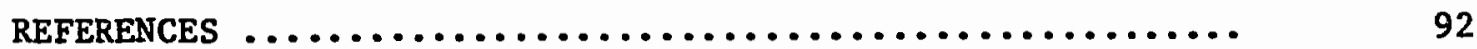
APPENDICES

A QUESTIONNAIRE MATERIALS ................... 103

B 1987 NAFE MEMBER SURVEY RESULTS ............... 114 


\section{LIST OF TABLES}

TABLE

PAGE

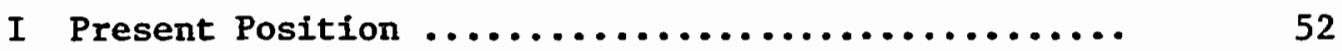

II Position Held Immediately Prior to Current Position 54

III Position Held Immediately Prior to Current Position

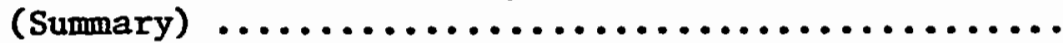

IV Type of Position Held Immediately Prior to Current Position ................................ 55

V Years in Present Job $\ldots \ldots \ldots \ldots \ldots \ldots \ldots \ldots \ldots \ldots \ldots . \ldots$

VI Years in Prior Job $\ldots \ldots \ldots \ldots \ldots \ldots \ldots \ldots \ldots \ldots \ldots \ldots$

VII Positive Influences Mean Scores .............. 58

VIII Negative Influences Mean Scores ............... 66

IX Demographic Profile of Nontenured and Tenured Female Administrators ...................... 


\section{LIST OF FIGURES}

$\begin{array}{ll}\text { FIGURE } & \text { PAGE }\end{array}$

1. Positive Influences Mean Scores ............... 61

2. Positive Factors of Mobility for Tenured and

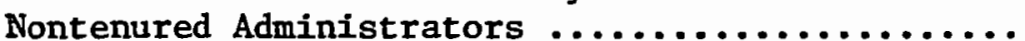

3. Negative Factors for Both Tenured and Nontenured Administrators ......................... 64

4. Negative Influences Mean Scores .............. 65 


\section{CHAPTER I}

\section{INTRODUCTION}

This study was proposed out of an interest in school adninistrator preparation and a concern about the lower ratio of female to male adninistrators in the education profession.

Interest in the area of female administration arose because curcent literature and my observation as a public school personnel adninistrator have demonstrated that there is a high female to male ratio in the education field as teachers, but aconinistrative positions are dominated by men. Feuers (1981) states that at the elementary level, 80 percent of the teachers are women and 83 percent of the acninistrators are men. Statistics show that as the grade level of education and the financial position status increase, the percentage of women in teaching decreases and the percentage of men increases (Schmuck [cited in Stockard, Schmuck, Kempner, and Williams, 1980]). The Oregon School Directory (1988-89), for example, cites only twelve women in superintendent or superintendent-principal positions out of the 304 school districts in the state. Only three are in districts having more than one school or student population greater than 500 , and one is an educational service district superintendent in eastem Oregon. At most, only about four percent of the top level adninistrative positions belong to women.

Education, as a profession in the United States, has been 
depicted as a woman's profession because of teaching. The first step in the education career ladder (teaching) has traditionally been dominated by women (Picker, 1980). Education aơninistration as a career for females gained respect following the Civil War, when women were hired as adninistrators (principals) to replace the men that had been lost during the war (Eutrell, 1981; Rosser, 1980). Following the depression of the 1930's and the Second World War, however, men were drawn to education in great numbers. Education generally offered security and opportunity for men of all ages. Men with leadership experience quickly climbed the organizational ladder from teacher to acninistrator. Colleges created departments of educational administration that actually favored men in leadership roles because of their leadership experience, coaching, or bureaucratic experiences, and not necessarily for their experience in teaching (McPheron and Smith, 1981, Rosser, 1980).

During the 1970's, particularly at the secondary level, teaching became more attractive to men as the salaries grew higher, due primarily to collective bargaining, and teaching also often provided a career path to both elementary and secondary adninistrative positions. This domination of management in education as a profession by males was not unique, since the majority of most professions in America have been dominated by men (Picker, 1980).

During the mid 1960's and into the 1970's, women were more anxious to get out of the home and enter the labor force. Like previous war time situations, women, during the viet Nam era, joined the teaching ranks, but unfortunately, their eagerness or their necessity to work, as in the past, kept the wages low. Eventually 
women again dominated the teaching profession and unfortunately, perpetuated the notion that teaching was a low status profession (Covel and Ortiz, 1978).

Progress toward equal opportunity in education for women has been slow in the decades since women became the majority in the education profession. (Applebaum, 1981; Blan [cited in Stockard et al]). Although women comprise a large talent pool, they continue to be underrepresented in the administrative ranks. Efforts to change the employment pattems for women are part of a larger social concern - eradication of sexism (Jewell, 1977; Terborg, 1977). Although steps have been taken to change this outright discrimination through state and federal laws, executive orders, litigation, and affirmative action plans, the results have been poor.

-. professions traditionally considered to be female because of large numbers of women in them, (e.g., teaching, librarianship, nursing, and social work) are administered by men. With the exception of nursing, these professions also tend to be among the most favorable for enabling men to rise to adninistrative and managerial positions in proportions that far outnumber women. (Walker, 1981, p. 1)

Clearly, in education, it can be demonstrated that women are not achieving education management positions at a rate proportionate to their teaching participation in the profession, and at a time when female talent is available.

\section{STATEMENT OF THE PROBLEM}

Public school acministrative positions are largely dominated by men in the United States, although they are outnumbered by women in the profession (Walker, 1981; Grim and Stem, 1974). Curcent 
literature indicates that women administrators are increasing in numbers, but not increasing at a rate proportionate to male administrators (Feuers, 1981). Studies indicate (Dandorf, 1980) that most women find it difficult to break into administration. Several studies identify barriers and negative factors, such as lack of educational preparation and fear of, or actual gender discrimination, which may exclude women from administration in education (Barter, 1959; Dole, 1973; Van Meir, 1975; Barnes, 1976).

Literature that identifies the factors which influence upward career mobility for women in the field of education administration does not abound, nor are there clearly identified models to follow. The problems identified for this study focus on two research questions:

1. What are the positive and negative factors that females believe have influenced their success in achieving administrative positions in education in Oregon Public Schools?

2. Through the use of the identified factors of beginning and successful women adninistrators and their demographic data, is it possible to create a profile that may enable other women aspiring toward a career in administration in Oregon to be more successful in their upward mobility in the acministrative ranks?

The lack of an identification of factors that attribute to upward career mobility and no clear model or pattem of success to follow are problems this researcher believes impact the upward career mobility of female acministrators. 
ASSUMPTIONS

The following are statements that the researcher believes to be factual, but cannot verify.

1. Respondents are willing to share their perception of their mobility so as to remove barriers to upward mobility in education acininistration for female educators.

2. Respondents will honestly rank those factors which are perceived to have had the greatest influence on their upward career mobility in education aconinistration.

3. Data collection will be sufficient to develop a personal/ professional profile of nontenured and tenured female adninistrators in the state of Oregon.

4. Response of the subjects will be sufficient to enable the researcher to make statistical judgements about female adninistrators' upward mobility, which will answer the research questions.

5. Instrumentation (questionnaire) is adequate to identify factors which do have significant impact on upward mobility for female education acministrators in Oregon.

\section{LIMITATIONS}

Limitations are those things that are beyond the control of the researcher that may place restrictions on the conclusions of the study and their application to other situations. The following are limitations the researcher believes may be inherent in this study: 
1. Female administrators may be reluctant to respond to a study conducted by a male concerning their upward mobility.

2. The inability of the researcher to accurately identify all female administrators for eligible participation was a concern. Some organizations are not allowed to release names or gender of their membership; not all names or gender are identified in directory information; and not all women in administration belong to the customary professional organizations. The subjects were limited to only those females identified in October 1988 by COSA as members.

3. A study was conducted at a specified point in time and doesn't represent an historical trend.

4. The study was conducted in a limited location.

5. Causation relationships cannot be inferred since the independent variables cannot be manipulated.

6. The degree to which subjects reported accurately their feelings and perceptions in the data collection is unknown.

7. The predictive ability of factors may be affected by the lack of variance since the subjects of the study may be homogeneous in terms of their education, and to some degree the way they encounter obstacles and employ strategies in their pursuit of upward career mobility. 
DEFINITION OE TERMS

The terms that follow are operational definitions of terms that may be otherwise used in the field of education. They are used frequently throughout this study and are used to define and identify Oregon women adninistrators in public education positions by this researcher:

1. Upward mobility: promotion or appointment to a position considered higher within the education adninistration profession (i.e. assistant principal to principal): a position change which requires greater job responsiblity due to the increased (total) number of individuals supervised.

2. Administrative position: A position above that of a classroom teacher or special teacher where the person is required to hold an administrative certificate as defined by Oregon Revised Statutes and Oregon Adninistrative Rule.

3. Nontenured adninistrator: An administrator that has fewer than three years experience in Oregon or elsewhere and is currently employed without tenure in an Oregon school district.

4. Tenured administrator: An administrator in an Oregon school district that has achieved tenure in Oregon or an adninistrator that, as the result of a position change from another state or district, achieved or would have qualified for tenure as an administrator in Oregon due to at least three years of successful evaluation. 
PURPOSE OF THE STUDY

The first purpose of the study was to delineate which of the factors identified by Jones and Montenegro (1982), have had a positive or negative influence in upward career mobility of female school administrators in Oregon. The findings of the study add to the research literature on this topic and may reveal added information and direction of interest to administrators of university adninistrative training programs, school board members and school personnel administrators involved in hiring and providing training or staff development. As a result, the commonalities and differences among female school aơninistrators in Oregon are identified.

A second purpose of the study was to provide, from the demographic and upward career mobility factors provided by aspiring and successful female acministrators, a profile that identifies those practices and qualities that have proven to be effective when considering career decisions in school acministration. Future female adninistrators should become aware of the assets women currently possess, and acquire and use those which best enable then to secure a position and succeed as a school acministrator.

This study should help make all administrators more aware of the potential of female adninistrators or females as adninistrators at a time when, according to the Confederation of Oregon School Administrators, (COSA), 50 percent of the acministrative positions in the state will be vacated in the next five years, primarily by men who will be retiring. Additionally, the study provides information about the effective and imnovative practices of tenured and nontenured 
female acministrators which can be universally applied to all aspiring and/or practicing male and female aconinistrators.

\section{METHOD OF INVESTIGATION}

The subjects selected were all female school administrators in Oregon. The subjects represented tenured and nontenured female administrators from elementary and secondary schools, district office staffs, and education service district staff personnel employed as supervisors, assistant/associate/vice-principals, principals, adninistrative assistants, assistant superintendents, and superintendents. Additionally, personnel administrators and superintendents in Oregon districts that employ significantly higher percentages of women than normal were interviewed.

\section{ORGANIZATION OF THE RESEARCH}

Chapter One contains the introduction to the problem, statement of the problem, the research questions, assumptions, limitations, the definition of terms, the purpose of the study, and a short overview of the methods and organization of the research. The remainder of the study is organized as follows: Chapter II contains a review of literature related to the study; Chapter III contains the research design, research questions, and methodology for the study; Chapter IV contains an analysis of data derived from the study and its relationship to the research questions; and Chapter $\mathrm{V}$ contains conclusions, implications and recomendations compiled as a result of the research. 
CHAPTER II

REVIEW OF LTTERATURE

\section{INIRODUCTION}

The review of literature contained in this chapter depicts an overview of women in educational adninistration. The chapter is organized into three areas: 1) An historical overview of administration which includes reference to significant issues that have impacted female adninistrative involvement; 2) Socialization, cultural and legal factors that have affected educational acministration for women; and 3) The present status of literature about female adninistrators in public education.

In an effort to use the most recent and pertinent literature concerning women in educational adninistration, a computer search of Educational Resources Informational Center (ERIC) and American and International Dissertation Abstracts, copies of abstracts and ERIC reports were obtained and reviewed. Additionally, publications from professional organizations, government publications, and periodicals were excellent sources of related literature on wonen in educational acministration.

Reeping in mind the previous references in Chapter I conceming the domination of management by men in education as well as other professions, the primary focus of this study is to identify and clarify the factors that relate to upward career mobility of women 
educational adninistrators in Oregon. In order to relate to Oregon women administrators, it is first necessary to understand the history, cultural, social and legal background that has shaped and changed the function of women in educational adninistration in America.

The majority of the related research in the field of education documents that women are currently underrepresented in educational adninistration positions in the schools of the nation and in Oregon as well, and further underscores the need for this study.

\section{HISTORICAL OVERVIEW}

Much has been done to document the statistics and actual differences between men and women in educational adninistration. Research studies in the 1970s addressed some of the causes. Affirmative action policies, Title VII of the Equal Employment Act of 1972, and Title IX of the Education Amendments of 1972 were viewed as major steps toward the goal of equitable representation of women in administrative levels of education. Several research studies have been undertaken on the national and regional levels to explore and explain the career patterns of women in educational administration, differences in the effectiveness of men and women adninistrators, recruitment and promotion barriers to women, and specifically, perceived barriers to advancement in educational adninistration (Pacheco, 1982; Rometo, 1983; Schmuck, 1975; Walker, 1981).

At the national level, The American Association of School Adninistrators (AASA) recognized the need to provide assistance to increase employment opportunities for women in a mid 1970 resolution which stated that: 
Women have historically played an important part in the education of the young, yet their areas of responsibility are still severely limited. The higher an acministrative position is in responsibility, prestige and salary, the less likely it is to be held by a woman (Jones, 1980).

In the mid 1970's AASA was awarded a grant by the Ford Foundation to implement a project to assist women interested in acininistration to advance professionally. The grant was a three year study which had at its initial phase, a series of workshops aimed at women presently in administrative positions who desired to become superintendents. The focus was primarily on assessments and mentoring activities. The second phase of this study centered around building support organizations for females beginning their first administrative position. Although the focus was on superintendent level positions, it was not long before state organizations like Northwest Women in Educational Administration (NWEA) became a voice for the advancement of women in administration on a regional and state level. The third and final phase of the AASA study focused on a series of conferences to explore means of funding, which were to provide equalization of opportunities for minority groups ("Climbing the Ladder", 1982; "Grant to Promote", 1977; "Network Helps", 1979).

Research abounds which shows women as a minority and hints at discrimination practices. In 1980 another AASA/Ford Foundation study, on the national level, resulted in the publication of Climbing the Career Ladder: B Research Study of Women in School Adninistration. This landmark study investigates barriers for wamen in school acministration, strategies used to overcome them, and factors relating to upward career mobility (Jones \& Mantenegro, 1982a). This study is 
currently being replicated by AASA and the complete results are to be published scon and available in late 1989 (AASA, 1988).

Guy (1979) conducted a study in Ohio involving earning a superintendent's credential. This study was designed to determine whether males and females have different career path expectations. His major goal was to determine why so few superintendents in Ohio were women. Gy found that the traditional views of the women's role, lack of formal preparation, sex discrimination, and personal and family constraints may or may not be barriers in career path expectations. Guy did find, however, that consolidation efforts in Ohio and the downward trend in student population accelerated reductions in administrative staff sizes. The downsizing caused a greater loss in female than in male administrative positions. Sanchez (1984) conducted a national study of female superintendents which focused on two elements: first, to identify positive factors that females believe influenced their achieving a superintendency, and second to compare the factors for women and men who were presently school superintendents. Sanchez concluded that when compared in four categories: family influence, role models, motivation, and personal characteristics, there were significant differences between male and female in all categories as a whole; a significant difference in gender between factors related to role models; a significant difference between male and female in motivation factors and a significant difference between male and female superintendents in the factors related to their personal characteristics. Another recent study conducted by Hines (1985) in Delaware focused on the present status of female educators and the perceived factors that impact 
upward mobility to top level administrative positions. Hines found in her study that female educators perceived that they were impacted positively in the areas of self-confidence, high career aspirations, decision making opportunities, better salary, appropriate college preparations and credentials, and general opportunities for advancement. Perceived sex-typing of occupations was the most significant negative factor impacting females securing aoministrative positions. Additional negative factors included: inadequate recruiting, inadequate networking, discriminating selection and hiring practices, family obligation, and the lack of a mentor or sponsor with clout. Pavlicko (1985) conducted a similar study in Ohio concerning the factors of upward career mobility. Pavlicko concluded that there are many well qualified women who are planning to assume greater reponsibility in the higher level adninistrative positions. Her respondents supported the belief that additional certification and a higher degree makes a candidate more competitive in the educational adninistrative job market. She also concluded that women have always been motivated, had high perseverance and no longer lack self-confidence or assertiveness, but were still reluctant to take risks. Family support or husband career conflict were not cited as negative factors. Like Hires, Pavlicko found that networking and sponsorship were necessary, but lacking in the clout or support needed to be effective. In sumary, Pavlicko, like the others, concluded that women were experiencing internal and external barriers in pursuit of upward career mobility, but they are aware of and are using many strategies to assist them in overcoming their barriers. 
Nationally, the rate of decline of female principals in the last twenty-five years has caused concern among trainers of educational acoministrators (Estimates of School Statistics, 1981-82; National Education Association (NEA), Research/Report, 1973). This decline, coupled with the fact that at the secondary level the number of female administrators has been small and is not getting larger in proportion to their representation in the profession, is cause for concern. This should be a concern for legislators, state and local boards of education, state departments of education and local school districts in implementing affirmative action programs, the results of litigation, and in complying with state and federal guidelines. A 1988 AASA study (Jones \& Montenegro, 1988), indicates that women are again making some gains.

In 1974 an Equal Employment Opportunity Camission (EFOC) report stated:

If a statistical survey shows minorities and females are not participating in your work force at all levels in reasonable relation to their presence in the population and the labor force, the burden of proof is on you to show that this is not the result of discrimination, however inadvertent. There is a strong possibility that some aspect of the system is discriminating (p. 47 ).

The corrmission further stated that practices and policies of recruitment, testing, selection, placement, promotion, appointment, and salary as well as fringe benefits are the most likely aspects of the system where discrimination occurs.

Many reasons are given for women being underrepresented in educational administration, such as low aspiration, lack of preparation and qualification, lack of leadership behavior effectiveness, and sex-typing of occupations. 
Low aspirations of women in education is not supported by EEOC data. Evidence abounds that shows women aspire to become administrators, but are thwarted in the upward progression toward adninistration (EDOC, 1974). Evidence is found in court decisions that clearly shows discrimination. In the last ten years, however, equal employment opportunity has begun to reopen in education.

Men, generally in charge of hiring, frequently made the charge that they could not find a qualified female. In 1973, Lyon and Saario made a study of State Departments of Education to substantiate or refute the claim that qualified women were not to be found. The study found that data were generally not collected according to gender. Schmuck (1987) documented that data are still not generally collected by gender.

In the area of leadership effectiveness, Morsink (1969) disputed the notion that females lack effective leadership behavior. In a 1986 study, Dixon studied the Oregon Assessment Center and identified that women typically scored higher than men in the Assessment Center process, but were still overlooked in selection. Dixon, Associate Director of the Oregon Assessment Center and Director of the Oregon Leadership Academy, found that supervisor support or mentoring had a significant impact upon professional development plans and perceived career opportunities for female candidates in the Oregon Assessment Center operated by the Confederation of Oregon School Adninistrators $(C O S A)$. Dixon further indicated that although mentoring had a significant impact on professional development and perceived opportunities, it could not be shown whether it influenced actual 
opportunity. The COSA study certainly does not indicate that women lack effective leadership behavior.

Sex-typing between occupations is perceived to be part of the problem facing females as they aspice to move into adninistration. Sex-typing occupations (assigning feminine or masculine labels to low level routine tasks) is closely related to sex-role stereotyping (Simmons et a1.. 1975).

Many of the successful female adninistrators in education, like Pat Schmuck, Professor of Ecucation at Lewis and Clark College, Portland, Oregon, have taken the time to write books and articles that account for their rise in adninistration. For women pursuing a career in school adninistration, these papers, monographs, and books summarize many concerns of aspiring female adninistrators. Heming (1981) summarized advice offered to prospective female adninistrators:

Fenales can succeed by - . working hard, being politically aware and able to "play the game", being well prepared academically, experientially, and specifically for issues which arise, setting goals and objectives to work toward, maintaining a sense of humor, and striving to be the crucial one and that opportunities exist for both males and females, provided they meet the requirements for the position in terms of ability, ecucation, and experience" (p. 5).

If you accept the Heming's statement and those of others like Pfiffner (1976), Breyer and Zalupski (1981), Adams (1979), and Lautzenheizer (1977), why then are women underrepresented in educational adninistration? Adams (1979) and Lauzenheizer (1977) suggest that while all the information that enables women to succeed applies to men as well, one trait does stand out with men that women seem to not display. Females must leam or be willing to take risks. Breyer and Zolupski (1981) indicate that perhaps most important is the 
ability to deal with the pressures that cone fron the job, personal lives, and from society. These challenges and risks are not insurmountable, but other writers have observed that it is assumed men can handle the previously mentioned conditions, but women must make it known or prove that they are capable and willing to accept challenges and risks. Another quality cited by all of the previously mentioned authors is that women should not be afraid to be women. Lautzenheizer (1977) writes that if a woman feels that being female is a limitation, then it is that feeling itself that could become the real limitation.

Through the 1970's and now, through the 1980's, we have witnessed a revolution in the pattems of wamen's lives. A 1976 EEOC research report indicated that women had an increased proportion of the labor market, lived longer, and were showing greater educational attainment. Throughout the 1980's many studies have been conducted on the Men vs. Women agenda. In the August 8,1988 , issue of U.S. News and World Report, devoted entirely to the Men vs. Momen issue, it was stated: "Biology may not be destiny, but these days researchers are finding some significant differences between the sexes and, in many ways, women are coming out ahead" (p. 50).

Politically, socially, and in management the "gender gap" is real, and literature documents that most of the gap is attributed to the less competitive nature of wonen. Alice Eaghy, a Purdue University social psychologist, studied 166 management students, hoping to find marked differences in management styles that are used in leadership positions. Eaghy surmised that the lack of differences might be due to the fact that many successful women deliberately imitate masculine ways. One consistent diffecence was found in the 
Purdue study. This study found that men tend to be more "autocratic", making their own decisions, while women tend to consult colleagues and subordinates more often (U.S. News, 1988).

Behavior studies at the University of Toronto have shown that men typically dominate discussions in small groups and spend more time talking than listening. Recently an example of this behavior was documented in an interview contained in an Oregon Schools Study Council (OSSC) article that quoted Scott Baker, a principal in the Estacada School District, as saying, after being observed by his PAL (Peer Assisted Leadership, NWREL) partner, Dr. Mary Smith, a Sandy School District principal, "Mary observed me working with a building support team. The feedback Mary gave me was that I was warm, friendly, and positive ...", but added Baker, "I was a talker and would out talk the teachers." As a result, he set a personal goal to improve his listening skills (Anderson, 1988).

Although earlier it was stated by Feuers (1981) that about 80 percent of the educational work force were women, a 1988 study by the National Center for Educational statistics cites that women comprise only 68 percent of the educational work force. Regardless of the percentage of wamen in the educational work force, the perception is slowly changing toward the realization that women can be good educational managers and leaders.

The history of educational acministration in public schools in America must be traced to the big city superintendents of the period from 1870 - 1900. Men of the period tended to be multi-faceted crusaders of the comman school movement. Horace Mann, 
Ellwood Cubberly, and George Strayer represented the driving force of the prominent educational leaders of the time. These men were lawyers, politicians, college professors, journalists, and religious men. According to Tyack and Hansot (1981), very few of the crusaders actually chose education as his life career. It has been well documented that educational leaders in the second half of the $1800^{\prime} \mathrm{s}$ were mostly Puritans from New England, strong and active church leaders, advocates of sunday schools and public schools, and pranoted social causes like temperance rather than teacher training. Ohles (1978) and Tyack and Hansot (1982) have both documented that very few of the educational leaders had made education a priority for their careers, and in fact, of the 74 leaders Ohles identified, only 418 had ever been teachers or principals.

National Education Association (NEA) documents show that early professionals (teachers and administrators) supported the early leaders of the educational movement. The leaders considered themselves to be the elite of the educational profession and concentrated their expertise in the area of character training (Tyack and Hansot, 1982). Men were often times known to front the ideas of women in the field of education. As male educators moved west and usually into other professions, women found their way into the classroom and a few, like Ella Flagg Young of Chicago, became superintendents. Unfortunately, at this period in our history, wages were low, and it was well documented that women worked for less than half of the same salaries that men were earning. This economic condition of a century ago is still the same underlying factor in the 
rapid feminization of the teaching profession today (Strober and TYack, 1981; Tyack and Hansot, 1982).

The power that men displayed as leaders in education was not unlike that experienced in society in general. Women, as educational leaders, slowly emerged under constraints imposed legally or by society, and devised their own strategies to influence education and women in society. Women educators, such as Erancis E. Willard, Mary Lyon, or Mary Catherine Beecher and Zilpah Grant campaigned their causes through a network of seminaries, co-workers, and strong feminist associations they helped to build. The leadership shown by women was powerful, but through their associations they were very careful to not disturb the status quo of the power of men. As a result, women were able to socialize and be effective with their male counterparts and often times persuade them to spend money, employ techniques, and use their power to achieve feminine objectives. Thus, as stated by Tyack and Hansot (1982), men often served as a front for women carrying out their activities.

Ella Flagg Young, the first female superintendent of Chicago Public Schools, was highly supported by wamen in the profession. Young was the first female president of the NEA. Through this association, women formed powerful lobby groups in support of the appointment of women to school acministration positions (Tyack and Hansot, 1982).

In the early part of this century, very few females held influential positions in education, and when they did, the positions usually offered poor pay and were generally considered by men to be less prestigious positions (Schmuck, 1975; Tyack and Hansot, 1982). 
For most of this century it has been well documented that women were not attaining the goals that leaders like Francis E. Willard, Ella Flagg Young, or Josephine Corless Preston had predicted.

The National Association of Elementary School Principals (NAESP 1981) documents that women have been losing ground in education acministration. Until recently, statistics on women employed as school administrators show that women have never been able to impact administrative positions for long. For example, in 1928, 858 of the elementary teachers were women and 558 of the principals were women. In the 1950's, women were still 858 of the teaching force, but were only 388 of the elementary adninistrators. In the 1960's and 1970's, teaching percentages were almost the same as previous decades, but administrative percentages for elementary had dropped to 228 and 188 for secondary. An upward trend began in the early 1980's, and at the present time it is believed that women occupy almost 258 of the elementary principalships and still occupy 858 of the teaching positions.

A recently completed American Association School Administrators' (AASA) survey indicated that in late 1987 and early 1988, overall gains of women in administration were about twice that of minorities. In 1987-88, nearly 308 of more than 113,039 school adninistrators for which data was gathered, were women. This was a 48 increase over 1984-85 totals. With 39 states reporting data on women and the superintendency, only 3.78 were wamen. This was, however, a 18 increase over 1984-85. Oregon percentages, at this time, seem to parallel national averages. The greatest rise in administrative positions was found in secondary assistant principalships and 
assistant superintendencies. The 1987-88 survey, conducted by Xenia Montenegro and overseen by AASA Associate Executive Director, Effie Jones, is the third undertaken by AASA to assess the status of women and minorities in educational adninistration.

Causes for the increase in educational management positions for men have been attributed, in part, to the cultural norms and socialization of women in society. Therefore, the next part of the study will focus on the ideas, issues, and factors that other researchers have attributed as reasons for these trends.

\section{SOCIALIZATION, LEGAL AND CULTURAL INFLUENCES}

ON WOMEN IN EDUCATICNAL ADMINISTRATION

Pat Schmuck, (1975) in her studies of wamen's careers in school administration, suggested that cultural norms have encouraged men to seek school management positions, and in the process, discouraged women from the same aspirations based on gender. Literature makes frequent references to various models and theories that have emerged as the basis for gender role association. The three most frequently cited gender role constraints that cause concem for women in their work, but are not job related are: psychologically self-imposed; family and marginality.

\section{Psychologically Imposed Concerns}

Based on research in the 1970's and documentation in the 1980's by educational researchers, it is believed that women are caught in a double bind (Horner, 1972; Schmuck, 1987). Women worry about success and failure from two perspectives: one, if they succeed, they are not living up to societial expectations of the female role; and two, if 
they fail, they are not living up to their own personal performance expectations. In either case, Ranter (1977) questioned the fear as being one of exposuce and visibility. The difficult part for women is that few role models can be found. As previously documented by NAESP statistics and reported by Biklen and Brannigan (1980), Schmuck (1975), Weber, Feldman, and Poling (1981), there are too few women in educational administration to provide role models. Estler (1975) documents that the literature shows that women are willing to take leadership roles in public/oomunity service roles, but for some reason are not as inclined to pursue leadership in education. Breyer and Zalupski (1981) attribute the difference to the fact that women seem to not want to take risks. Lautenheizer (1977) attributed the difference to being a fraid to be a woman. Research in this area needs further study so it can be determined why women refrain from taking risks and are not self confident. Although the question is now concentrated on women in education administration, the research additionally needs to determine if the behavior is indicative of all persons who may be weak in organizational or social skills.

Eamily Constraints

Research shows that the family role comes first for most wanen and the occupational role is secondary. Rather than pursue occupations that require time away from the family, extensive preparation educationally, and most importantly, an intercupted labor force participation, most married women have avoided careers of status, like those in school administration. Recent changes in demographics show that wamen are not as likely to remain married, and 
are not as likely to remarry when they are divorced from their spouse. As women have had to enter the work force playing the role of family provider, they have increasingly turned to higher status careers and professional aspirations of management in those careers. Darley (1976) documents this change and the change of fewer childcen or absence of children at home as a major change in the social status of women with respect to their jobs.

Many worren, as documented by Schmuck (1975), pass on opportunities in educational acministration because family comitments limit their movement to another community. Schmuck reported that women did not share the same feelings as men about moving their families during preparation stages. Women generally expressed that they were place bound because of their families. As a result of being unable to relocate, Villadsen and Tack (1981), as well as Schmuck, have reported that women often made second choices with their career options, and when offered an adninistrative opportunity, had to accept a very structured life organized around their family and career.

Although Villadsen and Tack (1981) identified the successful combination of the roles of wife/mother and acininistrative career as the key factor for success, they also documented that it was very important that their husband and children were supportive and assumed independence and household responsiblities. The importance of this support was reported to be important for psychological and financial reasons rather than for domestic reasons. Others have cited the psychological support of the husbands as being essential for success. Bogdan (1980) reported that as more mothers have entered the work force, they became more willing to identify motivational factors 
related to their going to work. Most often identified as a reason to work were financial reasons, wanting to get out of the house, contact with other acults and relief from child care. It has only been recognized recently that the effects on the children of working fathers has been ignored. Further, it is documented that society expects women to be with their children. This expectation influenced by the attitudes of society, coupled with maternal expectations for the children's well being, is commonly cited by many as a major obstacle for women (Stewart et al., 1982; Villadsen and Tack, 1981). Women have claimed for a long time that they have worked for financial reasons, but recently working women have mentioned non-financial reasons. In summary, it appears that women have always put their families before their careers. The trend, however, seems to be that women are now more often provided with the flexibility and opportunity to pursue their careers and provide for their families.

\section{Gender Issues in Education}

Increasingly gender issues are identified as being related to career choices and societal acceptance of women. In 1975, Estler examined social issues that affect the opportunities and aspirations of women in an attempt to explain their underrepresentation in educational adninistration. Estler indicated that role definitions show women as warm, helpless, humane, conscious of their upbringing, but were not described as leaders. Estler also cited prejudice as another roadblock involved in the selection process by school districts. Research has shown that regardless of the qualifications, 
women are often overlooked by men, who dominate the selection process (Clement, 1975; Estler, 1975; Faunce, 1977; Stockard, 1979).

Characteristics such as dominance, achievement, autonomy, and aggression are equated with the male image. Women are characterized as timid, emotional, passive, humble and respectful (Bach, 1976). Since leadership skills are usually described as male skills, it is assumed that women are socialized for different roles and responsibilities, such as counseling, curriculum specialists, and other positions subordinate to men (Bach, 1976; Epstein, 1971; Estler, 1975; Frasher and Erasher, 1979).

Discrimination of women is based on the fact that men hold most of the adninistration positions and tend to facilitate placement of persons like themselves. Women have systematically been excluded from administration and have had to modify their career designs to accept only those positions that were available.

In a paper presented at the Annual Meeting of the American Education Research Association in March, 1988, Myra Strober stated that, "Women, too, make choices about occupations. But women's choices are constrained by the fact that men make their choices first. Women have a smaller range of occupations from which to choose." Additionally, Strober and Arnold (1987) document that, ". . with such a large proportion of the jobs already filled by men, the employer would probably not have attempted to fill the positions . . they would have been marginalized, by being paid less and deemed ineligible for promotion opportunities."

In the area of leadership, studies do not measure actual competency, but perceived competencies. The few studies that have 
been done in this area support the belief that there are significant differences in the leadership behavior of male and female principals (Adkison, 1981; Gross and Trask, 1976; Morsink, 1970). This fact and the fact that there are few female role models are significant factors for women not entering adninistration (Estler, 1975).

A January 1989 article titled: "With a Little Help Fron My Friends", by Joan C. Johnson in Nations Business, documents mentors in Oregon and their effects on reaching the top rank in their careers. Mentoring helps women learn to do more than just deal with gender barriers. Mentors can help them assess their strengths, abilities, and opportunites. Mentors can often point out ways to get around obstacles and suggest ways to gain experience.

The one fact that seems evident is that some highly qualified professionals may not be provided the opportunity to use their ideas and skills in positions that are most suited to their aspirations and capabilities (Estler, 1975).

\section{Legal Factors Involving Women}

Not until the mid $1960^{\prime}$ 's did women really begin approaching equity in our society, and today equity is still a disputed issue. The social movements of the 1960's primarily focused on blacks and women, who, in part, concentrated their demands on the schools. In the search for equity and dignity, both groups initially believed that education was the place in which equal rights could be achieved. Feminists in the sixties used many of the same strategies of the blacks to gain recognition in their move to achieve justice and a sense of identity (Tyack and Hansot, 1982). 
Among the first of notable legislated changes for women was the Equal Pay Act of 1973, which amended the Fair Labor Standards Act and required all employers covered by the act to grant equal pay to men and women doing equal work (Jewell, 1977). Education, unfortunately, was not included.

The Civil Rights Act of 1964 was a major step toward forcing employers and institutions to look at equity and to eliminate discrimination in education, as well as all other areas in "The Great Society" (Tevis, 1981). Like the Equal Pay Act, the Civil Rights Act did not mention women as a group because it did not include, as a factor, discrimination on the basis of sex. It was not until 1972 that Title VII of the Civil Rights Act of 1964 was amended and included a prohibition of discrimination on the basis of sex and extended the law to public schools, which had previously been excluded.

In 1967 women were included as a protected class in the Age Discrimination in Employment Act (ADEA). This protected all workers 40-65 in all fields of work from discrimination on the basis of age. In 1974 this act was amended to protect workers from age 40-70.

Executive Order 11246 of 1965, which prohibited discrimination on the basis of race, religion, color, or national creed for institutions receiving federal contracts over $\$ 10,000$ also did not originally include women (Dorr, 1972). In 1976 this order was amended to include women (Tyack and Hansot, 1982).

In 1972 Title IX of the Educational Amendments stated that participation or benefits of a federally funded ecucational program could not be limited by discrimination in the protected areas and 
included gender. The greatest impact that has developed from Title IX was in the area of participation and sharing of funds in athletic programs. While not limited to athletics, Tyack and Hansot (1982), have noted that Title IX also applied to adninistration, curriculum, scholarships, and career counseling in ecucation.

Originally, three sections of the 1964 Civil Rights Act were of importance to women. By 1972, Title VII and IX had been amended to ecase gender discrimination. Title II, Vocational Education, was not changed to provide gender equity until 1976.

Legislation written specifically for women in education was first passed in 1974 as the Women's Educational Equity Act Program (WEEAP). Several programs have been designed and funded under WEEAP. Some of those that have had impact on educational leadership are: Female Leaders for Adninistration and Management in Education (FLAME); Delta Design for Leadership; Internship Certification; Equity Leadership and Support (ICES); and Leadership Training Attitudes (McPheron and Smith, 1981).

Discrimination based on gender has not been eliminated, but positive steps have been taken that have reinforced and provided women with legal opportunity toward equity and leadership in education.

THE PRESENT STATUS OF WOMEN IN EDUCATIONAL ADMINISTRATION (1980-88)

The decade of the 1970's ended with women being afforded greater rights, socialization, and acceptance in the work place in theory, but in fact, education adninistration saw little change for women. 
In the early $1980^{\prime}$ 's a slight upward trend began which brought the percentage of female elementary principals to 238 of the total (National Elementary Principals, 1981). At the secondary level, the same trend appeared to occur. Three percent females were reported by the National Education Association in 1970 (NEA, 1971). The National Association of Secondary Principals reported 78 in 1977, and in 1982 Jones and Montenegro reported the level of female representation to be ten percent. At the district office and superintendent level, the representation had not changed and was still less than $.5 \%$ of the work force.

In the early 1980's two studies had considerable impact on the focus of women in educational administration: The AASA, Aware Project, and the 1982 Jones and Montenegro study resulting in the publication, Climbing the Career Ladder: A Research Study of Women in School Administration. These studies investigated the barriers for women in school administration, the strategies used to overcome them and other factors relating to upward career mobility. The information provided by these studies appeared to give an immediate increase in elementary/secondary principalships. The most dramatic increase was a boost of 1.58 at the superintendent level (Jones and Montenegro, 1982b). Assisting women through awareness of mobility factors appeared to be successful in the 1977-1982 period. In the five years since 1982 the focus and interest in female adninistration has increased the national percentage of elementary principals to about 288 At the secondary level increases have been noted in vice principalships. At the district office level the percentage of women has remained about the same with a $3 \%$ national involvement. In Oregon 
there are currently (1988) twelve superintendents or superintendent/principals, or three percent of the state's population, according to the Confederation of Oregon School Administrators.

Women As Administrators

Each year in Oregon many administrative positions become vacant. Each district has a different selection method for administrators, but the local autonomy of school districts has clear implications for the hiring of adninistrators. One thing is clear, however, in the analysis of board involvement that impacts the hiring of women nationally, most board members are men. Even with affirmative action policies it seems all too clear that boards - predominately male, choose male adninistrators. Although the representation of women board members is higher in urban areas, they too are a minority. Even if boards do want to hire the best person for the job, ". . it is not surprising that predominately white and male boards tend to entrust this sacred responsibility (hiring) to someone like themselves - a white male." (Schmuck, 1987). Is one answer to the problem the involvement of more women as board members?

Pat Fitzwater of the Oregon School Boards Association (1989) reported that although no indepth study had been done for several years, the current membership is composed of 258 women and 758 men. These percentages are about what OSBA confirmed the last time a study was done, according to Fitzwater.

While much has happened since Title IX of the Education Amendment of 1972, mandating sex equity under the law, not much has happened in reality in the area of school adninistration. Each school district 
has been required to appoint a Title IX officer to ensure that educational opportunity and hiring are enforced. With no significant changes in the percentages of women hired as administrators since 1972, it is hard to believe that districts have done more than perfunctorily performed what has been necessary to ensure legal compliance.

Schmuck reported (1987) that public policy regarding sex equity has been eroded by the administration, the courts, and congress . . . even the public sentiment of educators is shifting away from considerations of gender equity. An analysis of educational reform reports by Tetreault and Schmuck (1985) concluded, "The reform books, comissioned reports selected for our analysis clearly indicate the past decade of legislation, new scholarship on women, research and action for sex equity in schools has gone unheeded. Gender is not a relevant category in the analysis of excellence in schools . . even Title IX is ignored." (1985, p. 63).

It appears that in the $1980^{\prime}$ 's public sentiment may put the gains of the 1960's and 1970's in jeopardy. Even though the interest in gender issues may not have increased, it is clear that from the gains that were made that there are new conceptual frameworks for building research and theories about women and education. Traditionally literature has stereotyped the role of women, but as feminists challenged the stereotype, a new scholarship on women emerged. The new scholarship on women suggests that the assessment of working women misleads and inadequately represents today's woman because it is based on old stereotyped assumptions (Bilkin/Shakeshaft, 1985). Schmuck (1987) divided the new scholarship of women into two categories. 
First a different analysis of data is made that searches for the theoretical framework by which to understand the work of women and is also critical of the notion of sex stereotypes. Secondly, it has undertaken new research to find out the actual behavior of women in the work place. Schmuck emphasizes that these approaches do not oppose each other. They actually build on each other. Researchers formerly paid little attention to what women actually did on their jobs. The characteristics of women at work only recently have been subject to study.

The depiction of women as part of our educational history is another part of the new scholarship. The exclusion of women in documentation of American education has presented a distorted view of history and created illusions about the involvement and ability of women. This misrepresentation has created a resurgence in educational Iiterature that restores women as a part of our educational history. Many scholars have been part of this movement - Kaufemen, Hoffman, Kerber, Lemer, Tyack and Hansot, Melder, and Flexner, are among those Schmuck (1987) cites as having restored women to their proper place in educational history.

More recently, however, the role of research in the area of gender interest in education has been conducted by scholars like Biklen; Lightfoot; Freedman, Jackson, and Boles; Apple; Shakeshaft; and Lather. Schmuck (1987) cites these researchers as contributing to the study of the behavior and influences of gender in education.

one last concern about gender issues must be discussed. Shulman and Sykes (1983) indicated that a result of the women's movement might actually be backlash. This "backlash" may have created a different 
mindset about the traditional professions of today and, in fact, be driving women to other business professions. Adkinson (1981) points out that in $1966,760,000$ women were enrolled in colleges of education and in 1979 the number was recuced to 601,000. On the other hand she points out that during the same period colleges of business gained from 204,000 to 819,000 in female enrollment. The reduction of the number of women involved in education may be a reason fewer are involved in administration. As Sykes (1983) pointed out, women inclined to be managers or administrators may no longer be as large a part of the traditional "female profession".

Pat Schmuck stated (1987):

Not only is teaching no longer the zenith to which young women aspire; it is often seen as the wrong choice for competent and capable women. The woman who chooses to enter and remain in education is seen as an anachronism in the eyes of her more liberated peers. Women who teach are often seen as "unliberated", ones who have not freed themselves from the cultural stereotypes about women's place in society. Perhaps a stereotype in reverse is operating; women who enter education (administration) do so because they are seen as adopting the denigrated position of women in the United States ( p. 93).

The new scholarship on women has no doubt raised the consciousness of all people about the abilities, needs and behaviors of women in education administration.

\section{Changes in Expectations}

Picker (1980) explored the conflict that continues between the trend that limits careers of women in adninistration and the pressures to increase opportunity in response to affirmative action. She found four distinct areas that were significant for career advancement of women in educational administrative positions:

1. Younger women are entering administration on a more equal 
basis with men. This means that women now spend the same number of years teaching as their male counterparts, where as in the past, women taught considerably more time than men before becoming adninistrators.

2. Women receive a more significant amount of sponsorship than male counterparts. Younger women receive slightly more than other women, but both receive more than older men, who receive more than younger men.

3. High career aspirations characterize female administrators. They attain more education and specific experience and a greater desire to advance on the career ladder. Women feel they are capable of making difficult and quality decisions, and additionally feel that they are well organized and are better able to cope with stress and family commitments because of their "cual role" experiences.

4. Female administrators perceive the existence of discriminatory practices and believe they must be more highly qualified than their male counterparts to overcome such practices. Women recognize they work in a male environment and may encounter discrimination in the process of selection and promotion.

The American Association Schools Administrators' study, Climbing the Career Ladder: $\triangleq$ Research Study of Women in School Administration (Jones and Montenegro, 1982a), provided an empirical investigation of barriers, strategies and other factors that contribute to the upward career mobility of women in educational administration. It is out of interest in this AASA research that the interest of mobility factors 
of Oregon Women in Administration grew. The instrument used in this research is modification of the AASA questionnaire. Recommendations from the AASA study were:

1. Other organizations should provide more support for women within the areas of job information, training, and available career opportunities in addition to institutional and moral support.

2. Women in school administration should be aware that their skills are transferable and may provide employment opportunities outside education.

3. Care in the selection and training of teachers with qualities of administrative interest or potential will result in long term benefits for gender equity in education administration.

4. Hiring and recruiting practices and policies should be examined or reexamined by boards or district administrators to assure equity for women and underrepresented groups, (Jones and Montenegro, 1982a). The AASA has continued to update this study periodically. A Comparison to Business Management

It has not been education that has opened its doors and enforced policy and changed practices which have better accommodated women as managers. Business and ecucational history have paralleled each other to a large degree in America. Since 1972, however, there seems to be a distinct increase in the acceptance of women as managers in the field of business. First, equal pay issues were addressed. Although litigation fostered some decisions, business managers were quicker to realize the value of having a more balanced work force (Jewell, 1977). 
Top level policy statements were uniformly formulated and announced throughout the organizations encorsing affirmative action. Today there are many monthly or periodic publications geared to women in business management; "Women's Guide to Management Positions"; "Executive Female"; "Savvy" and the usual women's magazines with numerous articles about women in management. Nations Business, May, 1989, highlights "The Age of the Woman Entrepreneur". This article indicates that women already own a third of all small business. This is a better percentage than those in educational adninistration.

Women have shown the greatest gains in administration beyond entrepreneurship in the area of sales, public relations and engineering.

Female Executive(1986), reported that females in engineering had risen from 1.88 in 1974 to $14.7 \%$ in 1984 ; one-third of the managers in sales in 1986 were women. This was a fifty percent increase from 1980.

The National Association for Female Executives reported in Executive Female (1987) that executive jobs are on the rise in career counseling, accounting, financial planning, real estate, health care, telemarketing, banking and insurance. Obviously, there are many more areas for opportunity in business, but each area shows a greater potential for female success than does education.

Female owned business rose 62.58 from 1980-1986. During that period male owmed businesses increased 33.48. In 1972 women owned less than 5 percent of American businesses. The rapid increase has experts, like Small Business Association's Carol Corckett, predicting, 
-. It is anticipated that women will comprise half of all self-employed people by the year 2,000." (Nations Eusiness, 1989). In Excoptional Entrepreneurial Wonen, (1988), Russel R. Taylor, director of the B. T. Taylor Institute for Entrepreneural Studies at the College of Now Rochelle, New York, profiles 15 women businss omers. Among the characteristics Taylor notes in his subjects are the ability to make things happen, self-confidence, and a drive for autonomy. Additionally, Taylor noted a high level of energy, exceptionally good health, and a regular program of exercise.

Nonetheless, the outlook is optinistic for women in business who choose the entreprenoural life. Sole proprietorship is often seen as a stepping-stone to ownership of larger, moce aggressive businesses, and no one knows yet how many women are "grachating" from sole proprietorships to partnerships and corporations. "I think women are realizing now how good they are. They realize they can compete," says Fran Jabara of Wichita State, where women make up 46 percent of the enrollment in entrepreneurship courses (Hations Business, 1989).

\section{SURARY}

The review of literature was divided into three areas: 1) An historical overview of recent events; 2) socialization, cultural and legal factors affecting acministration for women; and 3) the present status of literature about female participation in educational administration. This review documents that women were put in a "back geat" to men in the management of schools in America as well as in ocegon. The review documents the social and cultural influences on women as they pursue administration as an educational career. It 
shows how women have been discouraged, as well as the constraints applied to them as they have strived to become managers in a "man's profession". The review also explores the recent literature which advances theories in new scholarship about the role of women in society and in education.

The importance of knowing the factors of success and those things that others have recognized as factors of upward mobility were documented and cited as a partial solution to the underrepresentation of women in educational administration.

Creating a profile of an Oregon, female school administrator was a primary focus of the research. The research questions were designed to show if change was occurring by comparing the group of practicing nontenured and tenured administrators. The questions were raised primarily because of the interest and the presentation of information found in the works of Tyack and Hansot, Schmuck and Shakeshaft. The recency of their work and their findings caused concern about the development of women as adninistrators in the field of education. Shakeshaft compiled a profile of the female administrator from information she located in many sources. An intended result of this research was to provide a profile of practicing nontenured and tenured school administrators in Oregon and a comparison of their profiles.

The only recent standard found with which to compare the profile of Oregon women was presented by Shakeshaft (1987) in her work, Women In Educational Administration. Shakeshaft found the female administrator to be in her mid to late 40 's. If she was not white, she was somewhat younger. Blacks were younger than fhites, and Hispanic females were the youngest of all other racial and ethnic 
groups. She found that the higher the position in administration, the older the women were, and also found that $\mathrm{K}-12$ administrators were older than higher ecucation administrators. Picker, cited in Shakeshaft (1987), indicated that "younger women who enter adninistration are not waiting as long for administrative appointment as did their older female colleagues:" (1980, p. 146).

Shakeshaft further described the female administrator as coming from a rural background, most often the firstborn, raised in a two parent family, with more education than parents, more often married than not, Protestant, a registered Democrat, and a member of civic groups. Although Shakeshaft further describes the female adninistrator, those comparisons provide a guideline as comparisons are drawn between the research groups of practicing nontenured and tenured Oregon women school administrators. The standards docunented by Shakeshaft and others are those by which Oregon women will be compared. 
CHAPTER III

PROCEDURES

The purpose of this chapter is to describe the procedures that were employed to conduct this study.

The design of the study, a description of the population from which the sample was taken, and the instrumentation used in the data ollection are reviewed. The statistical procedures used and the variables investigated are also discussed in this chapter.

\section{THE SAMPLE}

The population selected for this study was 218 females certified and practicing adninistration in the state of Oregon identified as members of the Confederation of Oregon School Adninistrators for the 1988-89 school year. They were sent questionnaires concerning the upward mobility of female administrators in education. The respondents were given a three week period in which to respond. Fifty-four percent of the population (118), returned questionnaires within the three week collection period. The women responding to this study were sampled only as a whole population known to COSA, and were not necessarily all women administrators practicing in Oregon. 


\section{DESIGN}

Because existing variables could not be manipulated, this empirical investigation was designed to examine the internal and external factors that currently exist in female career mobility in educational adninistration in Oregon.

The research design chosen for this study included qualitative and quantitative analysis. Descriptive techniques employed included the reporting of demographic background, personal information relating to their mobility, such as family status, number of children, etc., and a self description inventory about personal and demographic characteristics of the involved adninistrators. The use of quantitative analysis was done through the use of the nonparametric test, Chi-Square (X) first because it is based upon discrete data rather than internal data. The nonparametric test is less precise, and therefore has less power than a parametric test, and is not as likely to reject a null hypothesis. The parametric test used was the t-test, which displayed the significance of the difference between the means of two independent groups. Chi-square (X) and t-tests were conducted to compare the likenesses and differences between the identified groups of successful and practicing administrators.

The rejection or acceptance of the null hypothese was based upon the .05 alpha level of significance. The 5 percent (.05) alpha level of significance is the standard for psychological and educational research. Rejecting a null hypothesis at the .05 level indicates that a difference in means as large as that found between 
the two groups would not likely have resulted from sampling error in more than 5 out of 100 replications of the experiment.

\section{INSTRUMENTATION}

The instrument used for this study was a modification of an instrument developed by AASA and used in their mobility studies of superintendents in the late 1970 's and early 1980 's during the AASA/EOrd Foundation workshops. Using the results of these early national studies of female career mobility in educational administration and the published results of the study: Climbing the Career Ladder: A Research Study of Women in School Administration (Jones and Montenegro, 1982a) adaptation was made to test the identified factors, not the identification of factors.

The AASA questionnaire was selected for this research because it has validity and reliability that were verified on a national basis. AASA validated the questionnaire through the following process:

1. Drafts of the instrument were reviewed by two researchers and two adninistrators. The reviewers evaluated the instrument in tems of clarity and appropriateness of the questions.

2. The revised questionnaire was prestested on a sample of at least seven school acministrators to determine its adequacy in capturing the required information and its ease in adninistration. The pretest respondents were also asked to provide other comments they might have had. Revisions were then made and the questionnaire finalized.

Like the AASA instrument, the modified instrument for this study was sent to four nontenured and four tenured 
female administrators. Modifications were made based on reaction to the instrument trial.

3. After the survey was completed and the responses analyzed, the reliability of the questionnaire was examined by means of an internal consistency measure (KR20), a statistical measure of internal reliability. The reliability estimate $(.60+)$ was found satisfactory. (E.F. Jones and X.P. Montenegro in Pavlicko, 1985).

HYPOTHESES

This study was designed to test empirically the most relevant variables (positive and negative) of upward mobility between the groups of nontenured (new administrators) and tenured (more than 3 years) adninistrators in the state of Oregon. Additionally, the study was intended to create a profile of Oregon female administrators and to compare those that have been successful to those aspiring to be successful after having achieved an aconinistrative position in education. The profile created is compared to suggestions made by Shakeshaft (p. 56-77) in Women in Educational Adninistration (1987).

Although the problem focus was previously stated as simple research questions, the two proposed research questions follow as statements of hypotheses in the null form:

1. There are no significant differences between tenured and nontenured female adninistrators in the factors they identify that have influenced their upward mobility.

2. There is no significant difference between the profile of a tenured and a nontenured female public school adninistrator 
in Oregon.

The general hypotheses were stated to determine the variables most relevant to upward mobility in this study and to document any difference between those factors as experienced or perceived by women new to acministration and those that have successfully worked as an adninistrator. Additionally, the creation of a profile of each group for the purpose of comparison was made.

\section{DATA COLLECTION}

Following review and approval for use of the instrument by the Human Subjects Review Committee at Portland State University, the questionnaire was mailed to all 218 female adninistrators identified as members of cosA currently identified as employed in oregon (fall 1988).

A cover letter explained the general purpose of the study and also outlined the directions for responding. A stamped, self-addressed envelope was included for the return of the instrument. Additionally a separate stamped, self-adiressed envelope was included to return an informed consent form and to insure confidentiality of the survey. No coding was used to identify the respondents. Fifty-four percent (118) of the questionnaires were returned as well as 548 of the informed consent forms. Two consent forms were not signed. All but 10 percent (99) of the responses came in the first week.

Prior to the actual mailing of questionnaires to the entire population, a sample test was conducted. The test sample included eight practicing female administrators, four of whom are nontenured 
(0-3 years) and four tenured ( $3+$ years). The response was 1008. The type of job experience was from superintendent/principal and vice principal. There were no high school acministrators used. All persons involved in the trial were elementary or middle school/junior high administrators. The questionnaire was challenged as to wording. Slight modification to the instrument was made based on the trial and discussion with dissertation advisor concerning implication and need for change. The trial was not analyzed for other than its readability by respondents. The trial persons were included in the final mailing. No attempt was made after the three week data collection period to increase participation in the study by sending reminder postcards or similar measures. The researcher felt that there might be a different mind set or attitude if respondents had a greater period in which to respond. If the study were to be conducted again, an attempt would be made to increase participation beyond a 548 response rate and to determine whether there was a difference in responses from early to later respondents.

The following is a list of the number and comments made concerning the instrument during data collection.

1) Put directions for each section at front of each section, not at the beginning of the instrument.

2) Could not finish .. I am unsure from directions if these answers are to be my assessment of how they impact me or women in general. (1)

The percentage of comments from respondents about the instrumentation was $1.75 \%$ of the total population. All comments concemed directions. 
Two were concemed with their location (1.688) and one (.848) was concemed about the clarity of the directions.

The informed consent forms contained the following corments:

1) "P.S. I wrote a master's on similar subject in 1985!" (1)

2) You could simplify consent form. (1)

3) "I get nervous with consent forms." (1)

4) "I have been put back into classroom due to budget reductions. - Good Luck!" (1)

5) "Purpose of research needs to be stated in letter." (1)

Comments were made on the consent form by 4.58 of the respondents. Three corments (2.75\%) were general in nature, one (.84\%) constructive, and one (.85\%) gave information.

\section{STATISTICAL ANALYSIS}

Descriptive statistics were used to analyze the following:

1) Demographic information and background of women in the sample.

2) The perceived positive and negative factors that have impact on career mobility on female aoministrators in Oregon.

3) The self-description inventory of personal characteristics.

4) The career pattems of women responding to the instrument.

The study also compared women new to educational administration (nontenured) and those who have been in adninistration (tenured). A parametric test ( $t$-test) and a nonparametric test (Chi-Square) were used to test the statistical significance of the proposed relationships between nontenured and tenured adninistrators. These relationships were also used to write a profile of each group. 
The statistical program, Statistical Package for the Social Sciences, SPSS, (Nie, Hull, 1981) was used. Tables were prepared from the data analysis using various program formats.

\section{SUMMARY}

Identifying the sample; establishing the design instrumentation and method of data collection; providing a review of the hypotheses; identifying the measures of statistical analysis to be used; and stating any additional limitations were outlined as an overview of procedures to be used in the investigation of factors of upward career mobility for women school aóministrators in Oregon.

The population of 218 women members of COSA was chosen as the sample, as most (95\%) of the adninistrators in Oregon belong to this professional organization. It also was believed that sampling the groups as a whole would give the most complete data.

The design of the study was emperical and included descriptive statistic techniques, nonparametric tests (Chi-square) and parametric tests ( $t$-tests). The instrument (see Appendix A) was a modification of the AASA instrumentation used and designed in the early 1980's by Jones and Montenegro.

The hypotheses centered around the dependent variables, positive or negative, perceived to be most relevant to upward career mobility of nontenured and tenured administrators (independent variables) in Oregon. In addition to the comparisons of factors for each group, a profile of each group and women administrators in general was constructed. 
CHAPTER IV

RESEARCH FINDINGS

INTRODUCTION

Presented in this chapter are the findings developed from data ollected in the following areas:
a) a description of the sample responses;
b) analysis of questionnaire returns;
c) a description of the sample
d) interviews;
e) research hyphotheses and findings; and
f) other findings related to the upward career mobility of female school administrators in Oregon.

\section{PRESENTATION OF DATA}

This study postulated that there were no expected differences between the groups of nontenured and tenured administrators and 1) the factors they identify that influenced their upward mobility or 2) their general demographic profile as groups.

Analysis of questionnaire Returns

The population selected for this study included 218 females working as administrators as identified by the Confederation of Oregon School Administrators (COSA). This population represented all women 
members of COSA except for student members who were not actually employed as school administrators. One-hundred-eighteen (118) responded to the questionnaire after a set three week data gathering period.

Additionally, 16 surveys were returned over a six week period after the initial three week data gathering period. These 16 were not included in the study. Although the inclusion of the late questionnaires would have statistically improved the response rate, it was believed that the longer response period might have contaminated the original group of responses due to an extended period of time in which to think about a response.

\section{DESCRIPTION OF THE POPULATION SAMPLE}

The surveys were coded (1) for the nontenured administrators and (2) for the tenured administrators. About sixty-four percent (64.38) of the population were nontenured and about thirty-six percent (35.78) of the respondents were tenured. The nontenured group was almost twice as large. This may indicate that there is at least a trend toward more women in administration, or it could indicate that there are more nontenured administrators in general.

Table I displays the number and percent of the positions presently held by the respondents and their status of being either nontenured or successful. 


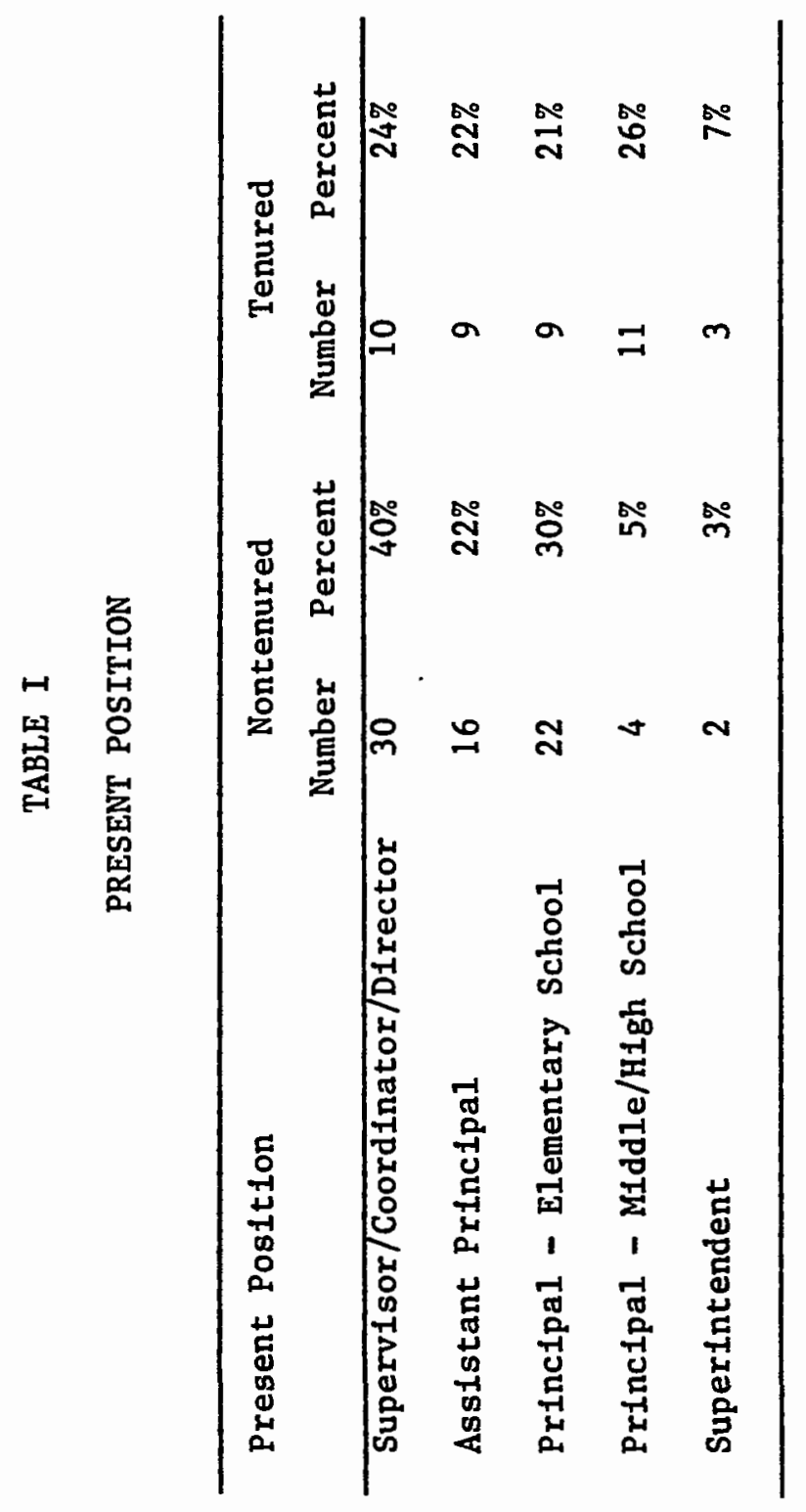


Prior to becoming acministrators, members of the two groups had been in a variety of educational positions. Both groups were composed of women that had preaviously been grade school classroom teachers (15.58); taught speech (14.78); taught English, been activities/attendance supervisor, coordinator, curriculum coordinator, or an acministrative assistant .98 of the time respectively.

Nontenured administrators had also been counselors (6.98); music teacher (1.78); and science, math, psychologists, media specialists/librarians, directors of instruction, or a teacher on special assignnent, each .98 of the time. Tenured adninistrators also had previous positions in teaching unique to their group. Tenured administrators, unlike nontenured adninistrators, had previously been athletic directors, youth employment coordinators, each .98 of the time. Tables II and III depict the position held immediately prior to the curcent position. Table IV is an overview of the types of all positions identified.

The position immediately prior to the first administrative position held for both groups was that of supervisor or coordinator. Nontenured acministrators frequently (50.08) had been supervisors, while tenured adninistrators (31.98) had been coordinators. Shakeshaft (1987) indicates that the usual progression is supervisor, then to the central office as a director or coordinator because of specific knowledge in an area. Generally this hierarchy is followed by a principalship at the elementary level and then, although less likely, a principalship at the secondary level. Table IV clearly indicates conformity to Shakeshaft's findings of 1987. 
TABLE II

POSITION HELD IMMEDIATELY PRIOR TO CURRENT POSITION

\begin{tabular}{|c|c|c|c|c|}
\hline \multirow{3}{*}{ Prior Position } & \multirow{2}{*}{\multicolumn{2}{|c|}{ Nontenured }} & & \\
\hline & & & \multicolumn{2}{|c|}{ Tenured } \\
\hline & Number & Percent & Number & Percent \\
\hline Teacher - English & 1 & $1 \%$ & 1 & $1 \%$ \\
\hline Teacher - Math & 1 & $1 \%$ & 0 & \\
\hline Teacher - Music & 2 & $2 \%$ & 0 & \\
\hline Teacher - Science & 1 & $1 \%$ & 0 & \\
\hline Teacher - Special Ed & 14 & $19 \%$ & 3 & $7 \%$ \\
\hline Teacher - Gradeschool Classroom & 16 & $22 \%$ & 2 & $5 \%$ \\
\hline Library/Media Specialist & 3 & $4 \%$ & 0 & \\
\hline Counselor & 8 & $11 \%$ & 0 & \\
\hline Psychologist & 1 & $1 \%$ & 0 & \\
\hline Consultant & 0 & & 2 & $5 \%$ \\
\hline Assistant Principal & 4 & $5 \%$ & 17 & $41 \%$ \\
\hline Principal & 2 & $3 \%$ & 10 & $24 \%$ \\
\hline Director of Instruction & 1 & $1 \%$ & 0 & \\
\hline Administrative Assistant & 4 & $5 \%$ & 2 & $5 \%$ \\
\hline Activities Supervisor & 1 & $1 \%$ & 1 & $2 \%$ \\
\hline Special Services & 2 & $3 \%$ & 0 & \\
\hline TAG Instructor & 1 & $1 \%$ & 0 & \\
\hline Athletic Director & 0 & & 1 & $2 \%$ \\
\hline Interim Administrator & 2 & $2 \%$ & 0 & \\
\hline TOSA & 3 & $4 \%$ & 0 & \\
\hline Public Relations & 1 & $1 \%$ & 0 & \\
\hline Youth Employment Coordinator & 0 & & 1 & $2 \%$ \\
\hline Coordinator & 5 & $7 \%$ & 2 & $5 \%$ \\
\hline Attendance Supervisor & 1 & $1 \%$ & 0 & \\
\hline
\end{tabular}


TABLE III

POSITION HELD IMMEDIATELY PRIOR TO CURRENT POSITION (SUMMARY)

\begin{tabular}{lrrrr}
\hline Prior Position & \multicolumn{2}{c}{ Nontenured } & \multicolumn{2}{c}{ Tenured } \\
\cline { 2 - 5 } & Number & Percent & Number & Percent \\
\hline Teacher & 36 & $49 \%$ & 6 & $14 \%$ \\
Assistant Principal or Principal & 6 & $8 \%$ & 27 & $64 \%$ \\
Other Non-classroom Position & 32 & $43 \%$ & 9 & $22 \%$ \\
\hline
\end{tabular}

TABLE IV

TYPE OF POSITION HELD IMMEDIATELY PRIOR TO

CURRENT POSITION

\begin{tabular}{lcccc}
\hline Prior Position & \multicolumn{2}{c}{ Nontenured } & \multicolumn{2}{c}{ Tenured } \\
\cline { 2 - 5 } & Number & Percent & Number & Percent \\
\hline Supervisor & 58 & $78 \%$ & 5 & $12 \%$ \\
Coordinator & 16 & $22 \%$ & 37 & $\mathbf{8 8 \%}$ \\
\hline
\end{tabular}


POSITIVE FACIORS

An obvious fact of the population sample is that nontenured administrators have less experience than their tenured counterparts. This fact is displayed in Table v. It was originally believed that there would be a difference in the two populations. Nontenured adninistrators were thought to be younger, have less educational experience, were more likely to have been part of more recent adninistrative trends, and therefore, different from the tenured adninistrator and have a very different adninistrative and personal profile as suggested by Picker (1980) and others in the review of literature.

It is also significant that, as demonstrated in Table $\mathrm{V}$ for the most part, nontenured administrators had been in their previous position a greater percent of the time. It is unknown why $8 \%$ of the nontenured persons indicated they had been in their position 4 years or more.

In addition to creating demographic information for a profile of women administrators in the two groups, a major purpose of the study was to look at the positive and negative factors that influenced the administrators and determine if there were significant differences.

Jones and Montenegro (1982) identified factors believed to be positive and negative influences to administrators. These lists were presented to both Oregon groups with no significant difference found between the factors using the nonparametric test, Chi-square. The list of positive factors included the twenty items listed on Table VI. 
TABLE V

YEARS IN PRESENT JOB

\begin{tabular}{lccccc}
\hline \multirow{2}{*}{ Number of Years } & \multicolumn{2}{c}{ Nontenured } & \multicolumn{2}{c}{ Tenured } \\
\cline { 2 - 5 } & Number & Percent & Number & Percent \\
\hline 0 to 3 Years & 68 & $92 \%$ & 28 & $67 \%$ \\
4 to 11 Years & 6 & $8 \%$ & 14 & $33 \%$ \\
\hline
\end{tabular}

TABLE VI

YEARS IN PRIOR JOB

\begin{tabular}{lcccc}
\hline \multirow{2}{*}{ Number of Years } & \multicolumn{2}{c}{ Nontenured } & \multicolumn{2}{c}{ Tenured } \\
\cline { 2 - 5 } & Number & Percent & Number & Percent \\
\hline 0 to 3 Years & 33 & $45 \%$ & 25 & $60 \%$ \\
4 to 7 Years & 20 & $27 \%$ & 9 & $21 \%$ \\
8 to 25 Years & 21 & $28 \%$ & 8 & $19 \%$ \\
\hline
\end{tabular}


TABLE VII

POSITIVE INFLUENCES MEAN SCORES

Nontenured Tenured $t$ Value Prob.

\begin{tabular}{|c|c|c|c|c|c|}
\hline 1. & $\begin{array}{l}\text { Adequate financial resources for } \\
\text { formal preparation. }\end{array}$ & 2.32 & 2.46 & -.69 & n.s. \\
\hline 2. & $\begin{array}{l}\text { High aspiration for an } \\
\text { administrative position. }\end{array}$ & 1.38 & 1.38 & -.02 & n.s. \\
\hline 3. & $\begin{array}{l}\text { College preparation and } \\
\text { appropriate credentials. }\end{array}$ & 1.62 & 1.40 & 1.40 & n.s. \\
\hline 4. & Approval from family and friends. & 1.91 & 2.31 & -2.00 & n.s. \\
\hline 5. & Increase job responsiblity. & 1.81 & 1.68 & .86 & n.s. \\
\hline 6. & Better salary/better benefits. & 1.89 & 1.81 & .50 & n.s. \\
\hline 7. & Co-worker/organization approval. & 2.30 & 2.17 & .65 & n.s. \\
\hline 8. & Supervisors Approval/encouragement. & 1.53 & 1.56 & -.19 & n.s. \\
\hline 9 . & Career role model. & 1.82 & 1.71 & .57 & n.s. \\
\hline 10. & $\begin{array}{l}\text { Opportunity for personal } \\
\text { advancement. }\end{array}$ & 1.55 & 1.63 & -.57 & n.s. \\
\hline 11 . & $\begin{array}{l}\text { Opportunity/professional } \\
\text { advancement. }\end{array}$ & 1.43 & 1.62 & -1.43 & n.s. \\
\hline 12. & Self-confidence. & 1.99 & 1.92 & .32 & n.s. \\
\hline 13. & Career role model of mother. & 3.57 & 3.52 & .20 & n.s. \\
\hline 14. & Marital status. & 3.07 & 2.77 & 1.15 & n.s. \\
\hline 15. & Level of teaching. & 2.98 & 2.71 & 1.05 & n.s. \\
\hline 16. & $\begin{array}{l}\text { Effective affirmative action } \\
\text { program. }\end{array}$ & 2.97 & 2.61 & 1.50 & n.s. \\
\hline 17. & Nondiscriminating hiring practices. & 2.36 & 2.07 & 1.24 & n.s. \\
\hline 18. & Flexible work schedule. & 3.22 & 3.24 & -.11 & n.s. \\
\hline 19. & $\begin{array}{l}\text { Equal distribution of work } \\
\text { assignment between sexes. }\end{array}$ & 3.07 & 2.07 & 1.48 & n.s. \\
\hline 20. & Assessment center review. & 3.01 & 3.07 & -.30 & n.s. \\
\hline
\end{tabular}


Table VII and later Table VIII represent the positive and negative mean scores respectively of a five point Likert-type scale. Respondents rated the positive and negative factors from (1) strongly agree to (5) strongly disagree. The questionnaire was reordered to allow this rating. Originally the questionnaire ordered the ratings: (1) strongly agree; (2) agree; (3) disagree; (4) strongly disagree; and (5) no opinion. To employ a Likert-type scale it was necessary to revalue the responses to (1) strongly agree; (2) agree; (3) no opinion; (4) disagree; and (5) strongly disagree. As is standard practice in survey research, the 5 points are assumed to constitute an equal interval scale when subjected to statistical analysis.

Describing characteristics of groups by using averages is generally understood by statisticians and nonstatisticians. The basis for comparison (average) was the mean or arithmetric average of the responses to each of the positive and negative factors. The mean was chosen since, in addition to the information that it provides, it is the base from which many other important measures could be computed.

Each factor (positive or negative) was analyzed as to the degree to which the groups agreed. Both groups agreed that having (\#1) financial resources for formal preparation was a positive factor. Nontenured and tenured strongly agreed that (\$2) high aspiration for the position was a positive factor. College preparation ( $\$ 3$ ) was also strongly agreed to as important. Approval of the family for the profession was also agreed to as important with a tendency to strongly agree. Increased responsibility (\#5) was agreed to strongly by both groups. 
A better salary (\#6) was rated agree to strongly agree by both groups as well. Approval by the organization (\#7) was rated agree to strongly agree, but 19.18 of both groups disagreed. Supervisor approval (48) was rated strongly agree by nontenured and tenured administrators. As to whether a mentor (49) was positive, both groups strongly agreed it was important. The opportunity for advancement (\#10) was also seen as being a strong positive factor. Career aspiration ( $\$ 11$ ) was seen as strongly agreed to as a positive factor. Self-confidence (\#12) was agree to strongly agree as a positive measure of success as well. The career role model of the mother (\#13) was disagreed to as a positive factor, but again by a majority of both groups. Marital status as a factor (\$14) was given no opinion by the largest percent by both groups. However, disagree as a response to it being positive was the second choice. The level of teaching (\#15) was given no opinion by both groups as to its being a positive factor. Effective affirmative action policies (\#16) in a district were agreed to but disagreed to by 28.78 of the total group. Even with the indecision, there was still agreement of both groups. Nondiscriminating hiring practices (17) were viewed by both groups as agree to strongly agree when judged as a positive factor. Flexible work schedules (\#18) were disagreed to as a positive factor by both groups, but a trend toward a difference of opinion appeared here when a greater percent of nontenured people disagreed and a greater percent of tenured administrators strongly agreed it was a positive factor.

Equal distribution of work between men and women (t19) also had a trend toward disagreement. More tenured women agreed it was positive while more nontenured women acministrators disagreed that it was a 
positive factor. Finally, the use of an assessment center (\$20) was rated "no opinion" by a majority with an almost equal number agreeing or disagreeing as to its value.

Figure 1 displays the complete picture with respect to the positive factors and the degree to which the two groups compared.

Both nontenured and tenured adninistrators agreed or strongly agreed that the items in Figure 2 show the positive factors about which respondents have no opinion and those items seen as not positive.

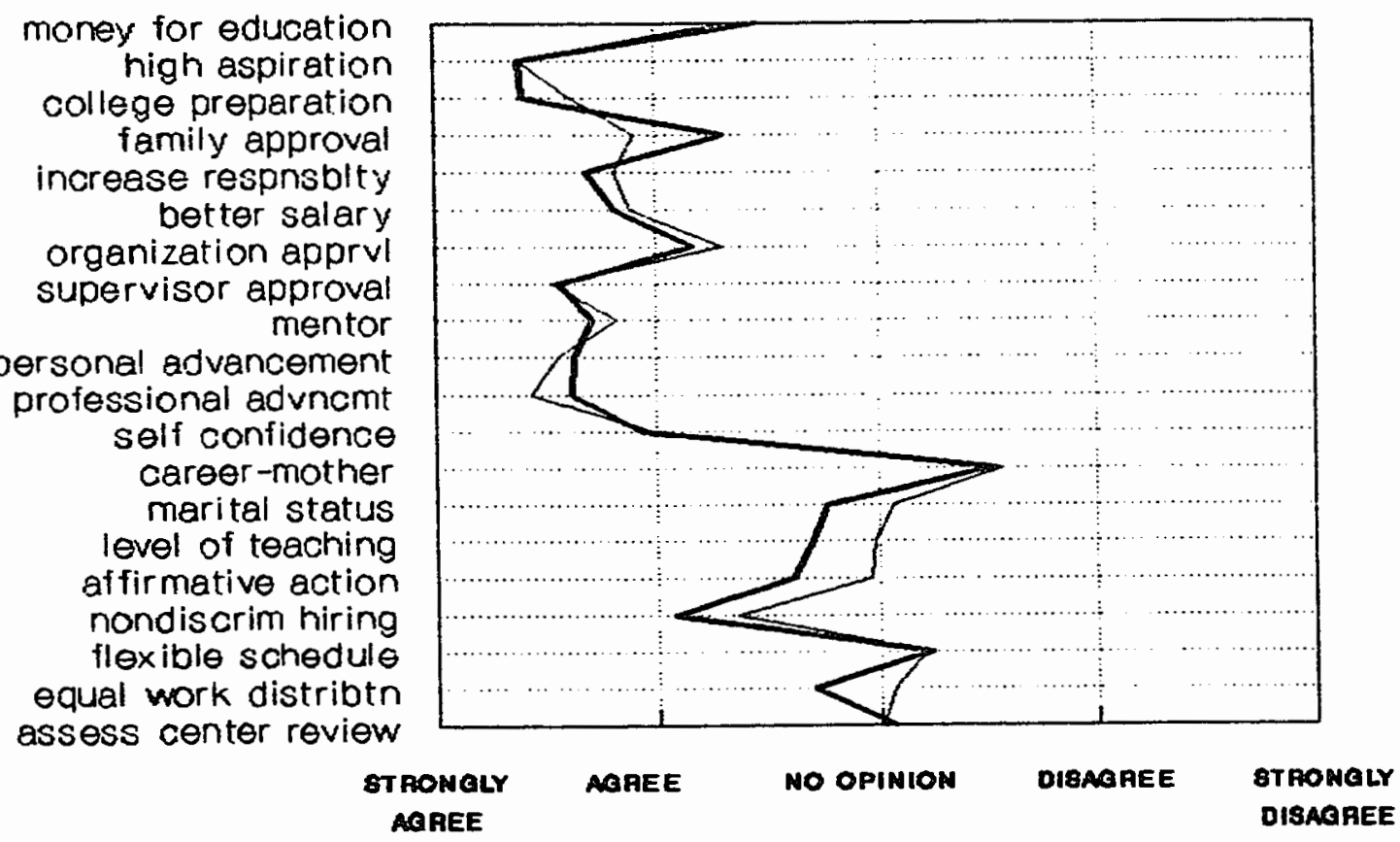

nontenured tenured

Figure 1. Positive influences mean scores. 


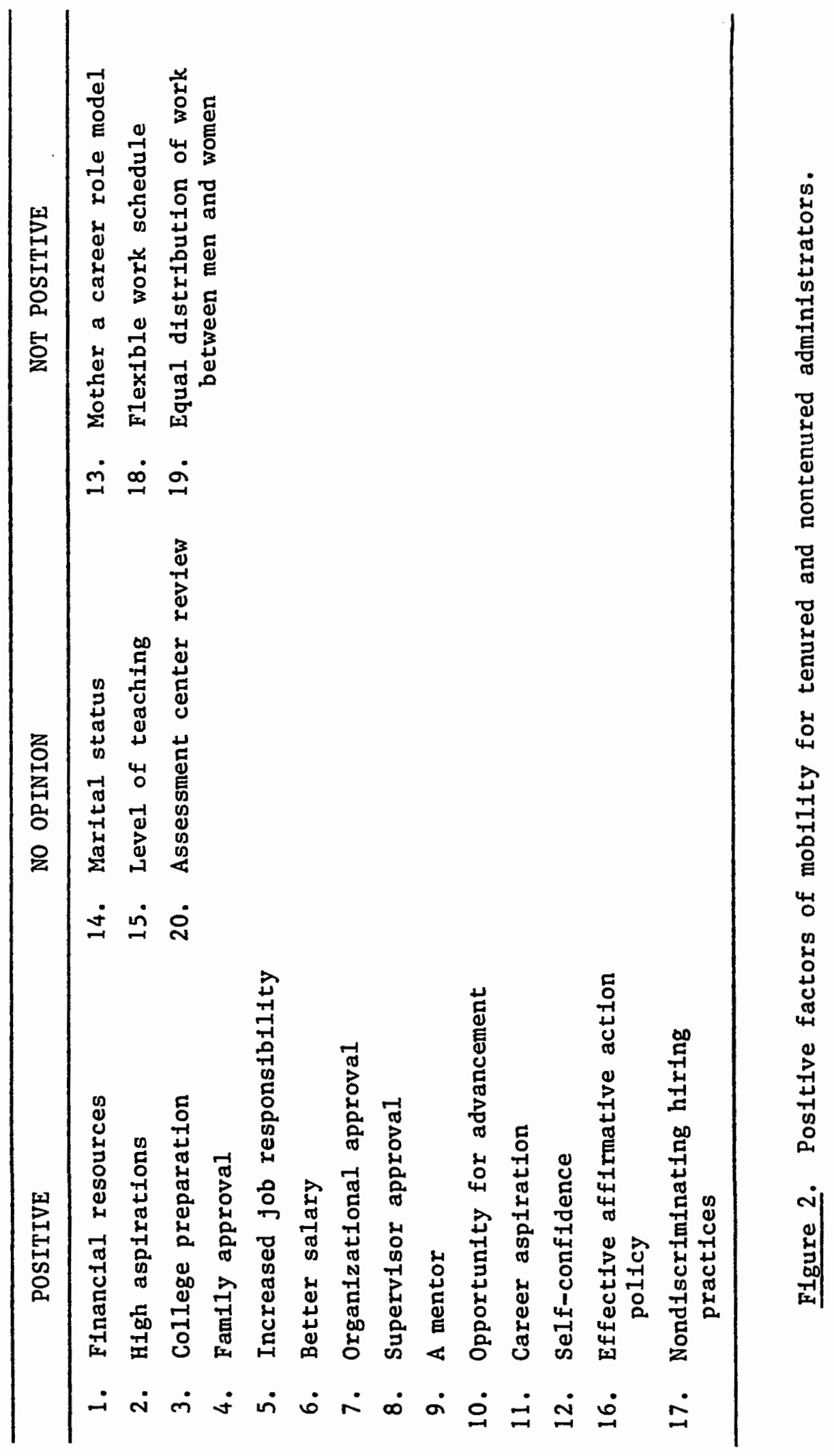


NEGATIVE FACIORS

Like the positive factors, Jones and Montenegro (1982a) identified factors that were perceived as negative to upward career mobility by female acministrators in education. They identified the list of items on Table VIII as perceived negative factors.

Figure 3 shows that both nontenured and tenured adninistrators agree that the list of items were negative factors of upward mobility or factors about which they had no opinion. Only one factor, the unequal distribution of work, had any significant degree of disagreement.

Although most indicators show a strong agreement between the groups, there was a trend toward disagreement in (\$4), absence of mentor and (\$13), unequal distribution of job activities between men and women. Although both agreed that they were negative factors, nontenured adninistrators tended to be more negative than tenured adninistrators. Figure 4 graphically displays the trends. The trends may be attributed to the cited stronger need for a mentor and to the initial desire to succeed as a new administrator.

It is also interesting to note that age, affirmative action, discrimination in hiring, and lack of encouragement from other females were not seen as negative factors in both groups.

Like Table VIII, Figures 3 and 4, demonstrate that a few negative factors show trends on $t$-test and one was significant e p<.005. Generally, no significant difference between the positive and negative factors to upward career mobility were shown. By demonostrating that little or no significant difference exists, the following null 


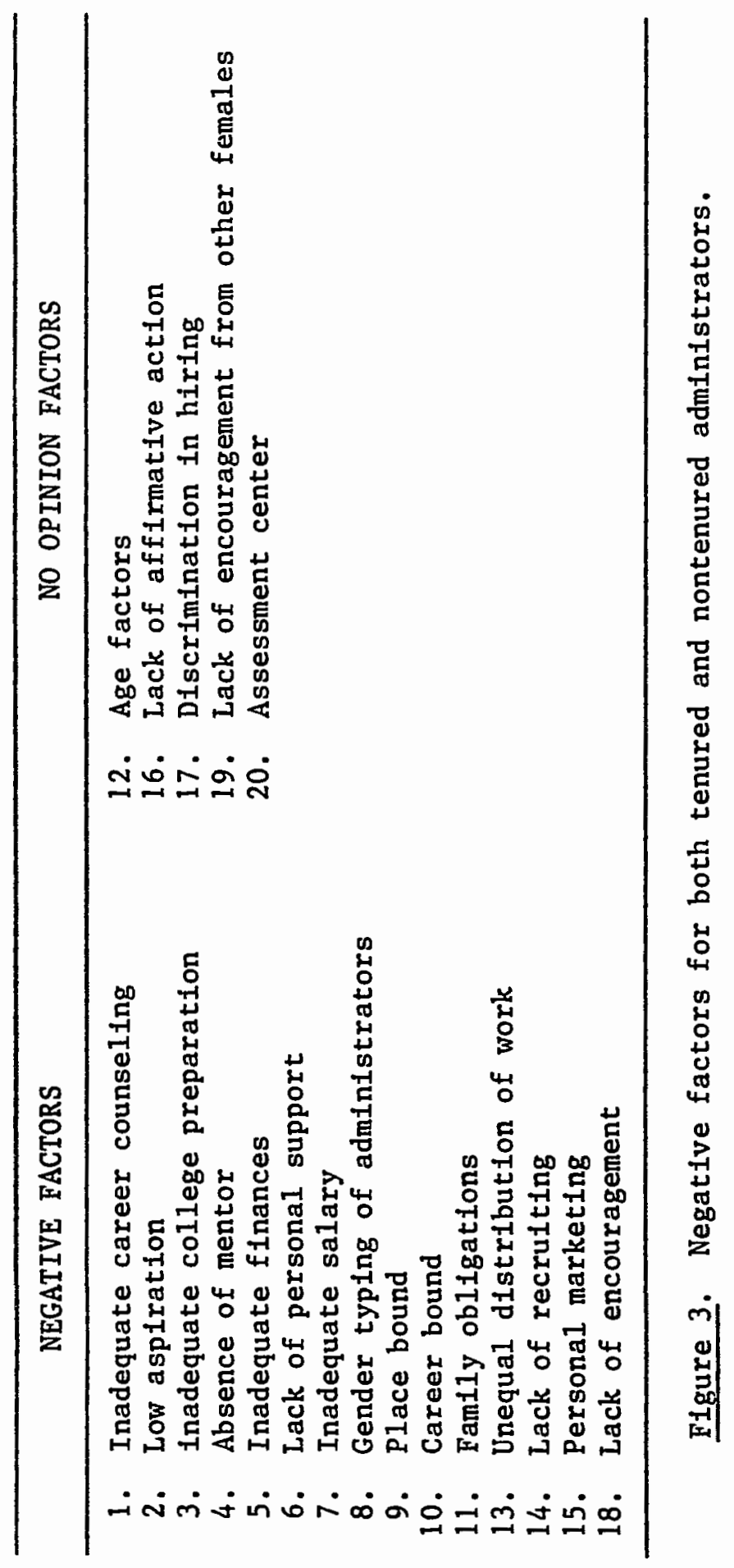


hypothesis is retained: There are no significant differences between tenured and nontenured female administrators and the factors (positive/negative) they identify that have influenced their upward career mobility.

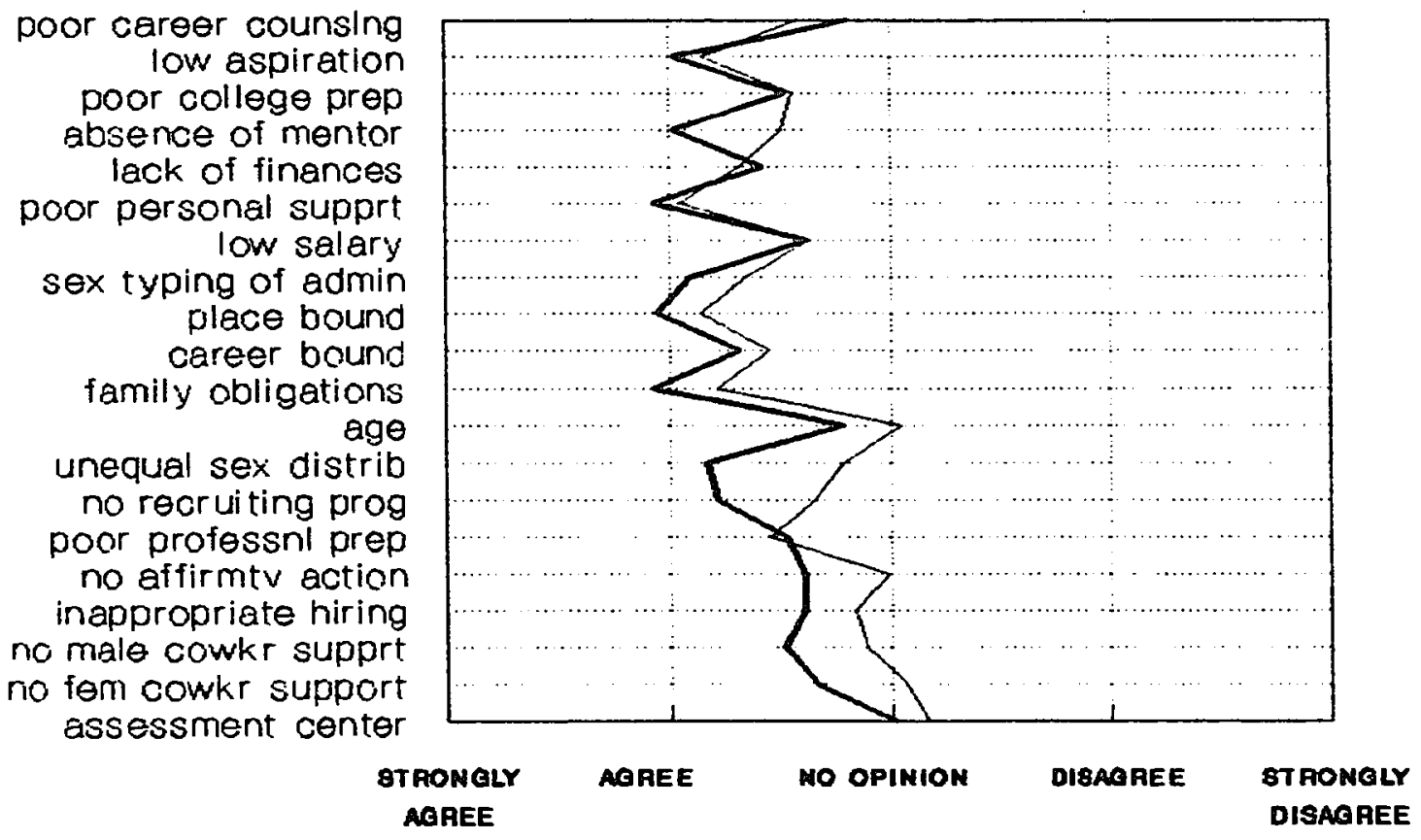

Nontenured _ Tenured

Figure 4. Negative influences mean scores. 
TABLE VIII

NEGATIVE INFLUENCES MEAN SCORE

\begin{tabular}{|c|c|c|c|c|}
\hline & $\begin{array}{l}\text { Non- } \\
\text { tenured }\end{array}$ & Tenured & t Value & Prob. \\
\hline 1. Inadequate career counseling & 2.58 & 2.81 & -1.00 & n.s. \\
\hline 2. Low aspiration. & 2.15 & 2.02 & .48 & n.s. \\
\hline $\begin{array}{l}\text { 3. Inadequate college preparation/ } \\
\text { credentials. }\end{array}$ & 2.55 & 2.52 & .12 & n.s. \\
\hline 4. Absence of mentor. & 2.50 & 2.02 & 1.93 & .056 \\
\hline 5. Inadequate finances available. & 2.32 & 2.43 & -.47 & n.s. \\
\hline 6. Inadequate personal support. & 2.05 & 1.93 & .58 & n.s. \\
\hline 7. Inadequate salary to support. & 2.62 & 2.62 & .01 & n.s. \\
\hline 8. Sex typing of administration. & 2.35 & 2.10 & 1.06 & n.s. \\
\hline 9. Place bound. & 2.14 & 1.95 & .87 & n.s. \\
\hline 10. Career bound. & 2.45 & 2.32 & .61 & n.s. \\
\hline 11. Family obligations. & 2.22 & 1.93 & 1.64 & n.s. \\
\hline 12. Age factor. & 3.05 & 2.79 & 1.18 & n.s. \\
\hline $\begin{array}{l}\text { 13. Unequal distribution of work assigned } \\
\text { between sexes. }\end{array}$ & 2.79 & 2.17 & 2.68 & .009 \\
\hline $\begin{array}{l}\text { 14. Lack of any recruiting, selection, } \\
\text { or hiring program. }\end{array}$ & 2.65 & 2.22 & 1.84 & .068 \\
\hline $\begin{array}{l}\text { 15. Inadequate preparation in personal } \\
\text { marketing. }\end{array}$ & 2.45 & 2.52 & -.37 & n.s. \\
\hline $\begin{array}{l}\text { 16. Lack of enforcement of affirmative } \\
\text { action policies. }\end{array}$ & 2.99 & 2.61 & 1.50 & n.s. \\
\hline $\begin{array}{l}\text { 17. Inappropriate hiring practices } \\
\text { experienced. }\end{array}$ & 2.84 & 2.61 & .84 & n.s. \\
\hline $\begin{array}{l}\text { 18. Little or no encouragement from } \\
\text { male colleagues. }\end{array}$ & 2.89 & 2.51 & 1.45 & n.s. \\
\hline $\begin{array}{l}\text { 19. Little or no encouragement from } \\
\text { female colleagues. }\end{array}$ & 3.07 & 2.66 & 1.62 & n.s. \\
\hline $\begin{array}{l}\text { 20. Use of assessment center where } \\
\text { results are limiting. }\end{array}$ & 3.17 & 3.02 & .70 & n.s. \\
\hline
\end{tabular}


THE PROFILE OF A NONTENURED ADMINISTRATOR

The second hypothesis of this study states that there is no significant difference between the profile of an nontenured and tenured female school administrator.

The typical profile of the nontenured female adninistrator in Oregon had previously been shown in this chapter to have been an elementary classroom teacher or a speech teacher that had as her first adninistrative position the job of supervisor or coordinator. She was most likely to be between 41 and 50 and second most likely to be between 31 and 40. She was most likely married and in her first marriage. A small equal percentage have been divorced and/or are remarried. If married, her husband had a college education and was considered to be in a professional position as opposed to holding a vocational position. Most frequently she had two children and was next most likely to have no childxen.

As she grew up, her mother most likely worked at a job considered to be vocational. About a third of the time her mother was a professional person. She most likely had one brother or no brother and was then next likely to have no sister. Most of the time she was the oldest child and next most likely to be the second of two children. She was identified a twin only twice in the population. For her religion she was dominantly Protestant. For her race, she was most likely Caucasian. In decreasing order, a small percentage of the women were Asian, Hispanic, or Black respectively. 
Two-thirds of the nontenured women administrators who had previously applied for a position indicated that they had been rejected in previous applications.

The nontenured adninistrators' level of income was equally distributed between 35-40 thousand dollars, or between 40-45 thousand dollars. If she did not make between 35 and 45 thousand dollars, she was next most likely to have an income of less than thirty-five thousand dollars. She had most likely not changed her position since she entered administration.

Before being an administrator, half of the women taught twelve or more years. She clearly indicated that she would not return to teaching even if the salary improved.

On the question of gender discrimination, about half of the nontenured women administrators felt that they had been discriminated against while slightly more than half felt they had not experienced gender discrimination. She felt, however, that she had been personally discriminated against. She was positive that she had been personally discriminated against, but stated a mixed reaction on gender discrimination. She also stated that she had not been discriminated against financially. Professionally, however, the nontenured administrator felt discrimination had occured. No survey question specifically asked why. Finally, in the area of discrimination, beyond gender, personal and financial, a large percentage of the population had experienced no other form of discrimination.

The nontenured female had been dominated by men about a third of the time. Fewer stated domination less than a third of the time, but 
one quarter of the women stated they had experienced no male domination. Most of the time her role models were both male and female, and least likely only female.

She described her present setting as most likely being rural or from an area in an agricultural setting. Suburban, or outlying parts of a city, followed by urban as characterized by city dwellers was next likely. The administrator described herself as least likely from an inner city demographic setting.

She was most likely from a rural area of Washington, Clackamas, Lane, or Marion counties. Almost half of the nontenured female adninistrators were from four rural or suburban areas of counties near Portland, Eugene, or Salem. Finally, there were almost twice as many nontenured administrators in the sample population compared to the percent of tenured administrators. The identified population was the 1988 October female membership of the Confederation of Oregon School Adninistrators (COSA).

The Portland public school's personnel office and the Confederation of Oregon School Adninistrators reported that two-thirds (66\%) of Portland's building level acministrators or principals belong to COSA and would have been included in the study. A smaller percentage (508) of district office level administrators belong to COSA. The state wide average includes about $95 \%$ of all levels of administrators as COSA members. Therefore, fewer urban administrators from the Portland area could have been initially included in the study, accounting for fewer urban or inner city persons. 
THE PROFILE OF A TENURED ADMINISTRATOR

The tenured administrator was also between 41-50 years of age. She was next most likely to be between $31-40$ years old. This was very much like the nontenured adninistrator.

The tenured administrator in Oregon was most likely married, next most likely to be divorced, and remarried. This too was very similar to the profile of the nontenured adninistrator. Her husband had a college education and, if not, had at least a high school ecucation. Most often her spouse was in a professional occupation. This too was very similar to the nontenured administrațor.

The tenured administrator generally had two children, and then was most likely to have had no children. This again was very similar to the nontenured administrator. Like her nontenured counterpart, as she was growing up, her mother worked at a vocational position. As she grew up, she most likely had one or no brothers, and then less likely to have been the second sibling. Most of the time she was the oldest child in the family. Unlike her nontenured counterpart, she had no twins as siblings in the sample population.

The tenured administrator grew up as a Protestant. If she was not Protestant, she was next most likely to be a Catholic. Ethnically she was Caucasian, and if not Caucasian, by small percentages was equally likely to be Black, Asian, or Hispanic.

When she previously applied for employment as an adninistrator, seventy-four percent of the time she had had a refusal. Twenty-six percent of the time the tenured adninistrator achieved an adninistrative position on her initial application. Her present 
administrative salary was most likely 40-45 thousand dollars, next likely 45-50 thousand dollars, and then less likely to be between 35-40 thousand dollars. The tenured adninistrator earned more than her nontenured counterpart. This may have been due to the time of employment as an administrator as being a primary wage factor for line and staff administrators in education. Almost thirty-eight percent had made no adninistrative career change. If a change was made, it was, by small numbers, from an elementary position to a district office position or from a secondary position to a district office position.

The tenured administrator taught almost equally 9-12 years or 6-9 years before becoming an adninistrator. When asked whether she would retum to teaching if the money were better, she said she would not. When the tenured acninistrator was asked whether she had been discriminated against, her responses were mixed. Fifty-six percent of the time she indicated she had been discriminated against by gender. By an almost equal percentage she indicated she had been personally discriminated against. Financially, she indicated she had not been discriminated against, but professionally, she had been a victim of discrimination. Beyond these four areas, little indication of other types of discrimination had been experienced.

The daminance of the tenured administrator's career by men was not frequently cited. Men and women were cited more often as having been role models for her career. Another female was seldom named as having been a role model. This, like the other areas, parallels the nontenured administrator's progress in education administration. 
The tenured adninistrator, like the nontenured adninistrator, was most likely to work in a rural setting. Suburban and urban settings were identified as the next likely settings in which a tenured adninistrator worked. Like the nontenured adninistrator, the tenured adninistrator seldom worked in the inner city.

The tenured administrator, like the nontenured administrator, primarily lived in one of four counties near the metropolitan areas of Portland, Eugene, or Salem. Rural Lane and Washington counties were most likely where she would live, while Clackamas and Marion counties were less likely respectively.

\section{EDUCATION LEVEL}

The education level of the profile was treated separately so as to better compare the homogeneity of both groups. All administrators in the sample have a bachelor's degree. Most achieved the degree between 1965 and 1975. The year with the highest B.A. graduation rate with 12.28 of the nontenured administrators and 11.98 of the tenured administrators graduating was 1968. All administrators in both groups also had master's degrees. Most were achieved between 1971 and the present, with almost equal annual percentage distribution between the two groups. Most of the administrators in both groups received their administrative certification between 1980 and 1988.' The greatest percentage (57.88) received their certification between 1984 and 1987 . More nontenured administrators were certified in the 1984-87 time period than tenured administrators. Tenured administrators were more frequently certified in 1981 (9.58), 1984 (11.98), 1985 (9.5), and 1986 (16.78). 
For wonen administrators, Shakeshaft (1987) cites that a doctoral degree was more prevalent as a percentage of the population than it was for men in the profession. This study indicates that 11.28 of the total sample have doctoral degrees. Nontenured administrators have 8.18 of their group with a doctoral degree, while 16.78 of the tenured group has a PhD or EdD degree.

Table IX documents the strong demographic similarities of both groups and also proves to retain the study's second hypothesis that: There is no difference between the profile of the nontenured and tenured Oregon school aơninistrator.

\section{SUMMARY}

The data demonstrate that as administrators there is little difference between women beginning a career and those that are successful. Two negative factors show a tendencey toward being significant. Those factors are: 1) the absence of a mentor a P<.056 and 2) the lack of recruiting efforts for women $\mathrm{P}<.068$. One negataive factor is significant at $P<.05$. That factor is the unequal distribution of work between men and women (.009). The likenesses of both groups are also very great when the positive factors are compared. With the positive factors there are only strong similarities, no significant differences or trends. With the many similarities, this information should be helpful to those wanen who, in the future, may aspire to be public school acministrators.

Although there are same differences, most of the personal characteristics cited by nontenured and tenured female respondents 
were very similar, as were the citing of the positive and negative factors tested.

The following conclusions were made from the data collected in this study:

1. Negative factors impacting both groups in the area of upward mobility include: sextyping of administration, inadequate career counseling, inadequate personal support (networking/professional group), inappropriate (discriminating) hiring practices, family obligations, and the absence of a mentor.

2. Positive factors impacting both groups include: self-confidence, high aspiration for an adninistrative position, increased job responsibility, remuneration, credentials/preparation and career opportunity.

3. Comparatively the groups did not differ significantly in their perception of the positive factors impacting upward mability.

4. Comparatively the groups also did not show a difference in their perception of negative factors.

5. The citation of no opinion about affirmative action policies was questioned in interviews with four Portland area district personnel adninistrators. In districts having the highest proportion of women administrators, all personnel administrators concluded that the chief administrator's personal philosphy, not board direction, about affirmative action was the key to their greater employment ratio of women. 
6. The profiles of nontenured and tenured female adninistrators in Oregon indicated that they were married with two children or less, had undergraduate and graduate degrees in education, ranged in age between 32-60, had a husband who was college educated and worked as a professional in trade or industry, were Protestant, Caucasian, aspired to administration for leadership opportunity, were personally respectful of others, hardworking, conscientious, intellectually competent, self-confident and optimistic.

7. The rural life was most frequently described as the female administrator's demographic setting. It is unknown whether this is a place bound or career bound condition. Both conditions were described as negative factors of upward mobility. However, it has been said of acninistrative positions for men or women that you start your way up the career ladder generally away from the city and work toward the city or larger positions.

8. The problem of female involvement is not an individual one, but rather a concem to society as a whole. As more women aspire to professional and management positions, widespread inequities, practices and tendencies in the area of upward mobility must be presented to leaders, given focus and direction toward eradication. This problem is obviously one of considerable social significance and attitude change for management as it presently exists, dominated by men and its male history. 
In a December 1988 interview, Pat Schmuck indicated that until men are proven that the cultural stereotype about woman's place in society is broken, sex bias in education will continue. Perhaps as Pat Schmuck (1987) wrote,

. - efforts like the Boston Women's Teachers' Group, the Research on Women in Ecucation of the American Educational Research Association, the National Association of Wonen's Studies, and the individual studies and dissertations of women teachers and administrators can restore a proper perspective to the study of gender as it relates to educational institutions. Perhaps, for the first time, we will have an educational reform platform which simultaneously recognizes the value of education and the value of women in our United States (p. 93-94).

Implications of the data are discussed in Chapter $\mathrm{v}$, and conclusions are drawn that are intended to help women achieve greater equity as administrators and help find ways to improve the development of women as adninistrators in education. 
TABLE IX

DEMOGRAPHIC PROFILE OF NONTENURED AND TENURED FEMALE ADMINISTRATORS

\begin{tabular}{|c|c|c|c|c|}
\hline \multirow[t]{2}{*}{ Demographic Variables } & \multicolumn{2}{|c|}{ Nontenured } & \multicolumn{2}{|c|}{ Tenured } \\
\hline & $\overline{\mathbf{N}}$ & $\%$ & $\mathrm{~N}$ & $\%$ \\
\hline $\begin{array}{l}\text { Age } \\
\begin{aligned} 31-40 \text { years } \\
41-50 \text { years } \\
51-60 \text { years } \\
\text { Over } 61 \text { years }\end{aligned}\end{array}$ & $\begin{array}{r}31 \\
38 \\
5 \\
0\end{array}$ & $\begin{array}{r}42 \% \\
51 \% \\
7 \% \\
0 \%\end{array}$ & $\begin{array}{r}16 \\
23 \\
2 \\
1\end{array}$ & $\begin{array}{r}38 \% \\
55 \% \\
5 \% \\
2 \%\end{array}$ \\
\hline $\begin{array}{l}\text { Marital Status } \\
\text { married } \\
\text { remarried } \\
\text { separated } \\
\text { divorced } \\
\text { widowed } \\
\text { never married }\end{array}$ & $\begin{array}{r}42 \\
10 \\
4 \\
10 \\
0 \\
8\end{array}$ & $\begin{array}{r}57 \% \\
14 \% \\
5 \% \\
14 \% \\
0 \% \\
11 \%\end{array}$ & $\begin{array}{r}22 \\
8 \\
0 \\
8 \\
1 \\
3\end{array}$ & \begin{tabular}{r|r}
$52 \%$ \\
$19 \%$ \\
$0 \%$ \\
$19 \%$ \\
$2 \%$ \\
$7 \%$
\end{tabular} \\
\hline $\begin{array}{l}\text { Husband Education Level } \\
\text { high school diploma } \\
\text { some college } \\
\text { college degree }\end{array}$ & $\begin{array}{r}9 \\
21 \\
27\end{array}$ & $\begin{array}{l}16 \% \\
37 \% \\
47 \%\end{array}$ & $\begin{array}{r}11 \\
4 \\
16\end{array}$ & $\begin{array}{l}36 \% \\
13 \% \\
52 \%\end{array}$ \\
\hline $\begin{array}{l}\text { Husband Occupation } \\
\text { vocational } \\
\text { professional }\end{array}$ & $\begin{array}{l}12 \\
44\end{array}$ & $\begin{array}{l}21 \% \\
79 \%\end{array}$ & $\begin{array}{r}9 \\
21\end{array}$ & $\begin{array}{l}30 \% \\
70 \%\end{array}$ \\
\hline $\begin{array}{l}\text { Number of Children } \\
0 \\
1 \\
2 \\
3 \text { or more }\end{array}$ & $\begin{array}{l}20 \\
13 \\
28 \\
11\end{array}$ & $\begin{array}{l}28 \% \\
18 \% \\
39 \% \\
15 \%\end{array}$ & $\begin{array}{r}10 \\
4 \\
19 \\
9\end{array}$ & $\begin{array}{l}24 \% \\
10 \% \\
45 \% \\
21 \%\end{array}$ \\
\hline Child of Career Mother & 45 & $61 \%$ & 25 & $60 \%$ \\
\hline $\begin{array}{l}\text { Mother Occupation } \\
\text { vocational } \\
\text { professional }\end{array}$ & $\begin{array}{l}28 \\
16\end{array}$ & $\begin{array}{l}62 \% \\
38 \%\end{array}$ & $\begin{array}{r}18 \\
8\end{array}$ & $\begin{array}{l}69 \% \\
31 \%\end{array}$ \\
\hline $\begin{array}{l}\text { Number of Brothers } \\
0 \\
1 \\
2 \\
3 \text { or more }\end{array}$ & $\begin{array}{r}26 \\
35 \\
7 \\
6\end{array}$ & $\begin{array}{r}35 \% \\
47 \% \\
10 \% \\
8 \%\end{array}$ & $\begin{array}{r}14 \\
14 \\
6 \\
8\end{array}$ & $\begin{array}{l}33 \% \\
33 \% \\
14 \% \\
19 \%\end{array}$ \\
\hline $\begin{array}{l}\text { Number of Sisters } \\
0 \\
1 \\
2 \\
3 \text { or more }\end{array}$ & $\begin{array}{r}24 \\
28 \\
15 \\
7\end{array}$ & $\begin{array}{l}32 \% \\
38 \% \\
20 \% \\
10 \%\end{array}$ & $\begin{array}{r}13 \\
21 \\
5 \\
3\end{array}$ & $\begin{array}{r}31 \% \\
50 \% \\
12 \% \\
7 \%\end{array}$ \\
\hline
\end{tabular}


TABLE IX

DEMOGRAPHIC PROFILE OF NONTENURED AND

TENURED FEMALE ADMINISTRATORS

(continued)

\begin{tabular}{|c|c|c|c|c|}
\hline \multirow[t]{2}{*}{ Demographic Variables } & \multicolumn{2}{|c|}{ Nontenured } & \multicolumn{2}{|c|}{ Tenured } \\
\hline & $\overline{\mathbf{N}}$ & $\%$ & $\mathbf{N}$ & $\%$ \\
\hline $\begin{array}{l}\text { Position with Siblings } \\
\quad 1 \\
2 \\
3 \\
4 \text { or more }\end{array}$ & $\begin{array}{r}37 \\
24 \\
8 \\
5\end{array}$ & $\begin{array}{r}50 \% \\
32 \% \\
11 \% \\
7 \%\end{array}$ & $\begin{array}{r}19 \\
15 \\
5 \\
3\end{array}$ & $\begin{array}{r}45 \% \\
36 \% \\
12 \% \\
7 \%\end{array}$ \\
\hline 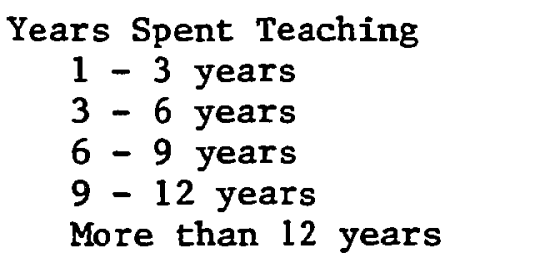 & $\begin{array}{r}2 \\
11 \\
13 \\
7 \\
40\end{array}$ & $\begin{array}{l}3 \% \\
15 \% \\
18 \% \\
10 \% \\
55 \%\end{array}$ & $\begin{array}{r}2 \\
6 \\
12 \\
13 \\
7\end{array}$ & $\begin{array}{r}5 \% \\
15 \% \\
30 \% \\
33 \% \\
18 \%\end{array}$ \\
\hline $\begin{array}{l}\text { Grade Levels Taught } \\
\text { elementary school } \\
\text { middle school } \\
\text { high school } \\
\text { elem and middle } \\
\text { middle and high } \\
\text { elem, middle and high }\end{array}$ & $\begin{array}{r}23 \\
7 \\
8 \\
12 \\
7 \\
6\end{array}$ & $\begin{array}{l}37 \% \\
11 \% \\
13 \% \\
19 \% \\
11 \% \\
10 \%\end{array}$ & $\begin{array}{r}8 \\
2 \\
13 \\
1 \\
4 \\
3\end{array}$ & $\begin{array}{r}26 \% \\
7 \% \\
42 \% \\
3 \% \\
13 \% \\
10 \%\end{array}$ \\
\hline Ever Taught Out-of-State & 33 & $45 \%$ & 14 & $34 \%$ \\
\hline If \$ Higher, Teach Again & 12 & $17 \%$ & 3 & $8 \%$ \\
\hline $\begin{array}{l}\text { Discrim Against By Gender } \\
\text { If yes, how: }\end{array}$ & 34 & $48 \%$ & 22 & $56 \%$ \\
\hline $\begin{array}{l}\text { If yes, how: } \\
\text { personally } \\
\text { financially } \\
\text { professionally } \\
\text { other }\end{array}$ & $\begin{array}{r}22 \\
8 \\
23 \\
6\end{array}$ & $\begin{array}{l}65 \% \\
24 \% \\
68 \% \\
18 \%\end{array}$ & $\begin{array}{r}13 \\
8 \\
21 \\
5\end{array}$ & $\begin{array}{l}52 \% \\
32 \% \\
84 \% \\
20 \%\end{array}$ \\
\hline $\begin{array}{l}\text { Difficulties w Male Dom. } \\
\text { none } \\
\text { very little } \\
\text { moderate } \\
\text { considerable } \\
\text { extreme }\end{array}$ & $\begin{array}{r}18 \\
22 \\
25 \\
8 \\
1\end{array}$ & $\begin{array}{r}24 \% \\
30 \% \\
34 \% \\
11 \% \\
1 \%\end{array}$ & $\begin{array}{r}7 \\
16 \\
13 \\
5 \\
1\end{array}$ & $\begin{array}{r}17 \% \\
38 \% \\
31 \% \\
12 \% \\
2 \%\end{array}$ \\
\hline $\begin{array}{l}\text { Gender of Role Models } \\
\text { male } \\
\text { female } \\
\text { both male and femal }\end{array}$ & $\begin{array}{l}26 \\
16 \\
28\end{array}$ & $\begin{array}{l}37 \% \\
23 \% \\
40 \%\end{array}$ & $\begin{array}{r}16 \\
6 \\
16\end{array}$ & $\begin{array}{l}42 \% \\
16 \% \\
42 \%\end{array}$ \\
\hline
\end{tabular}


TABLE IX

DEMOGRAPHIC PROFILE OF NONTENURED AND TENURED FEMALE ADMINISTRATORS

(continued)

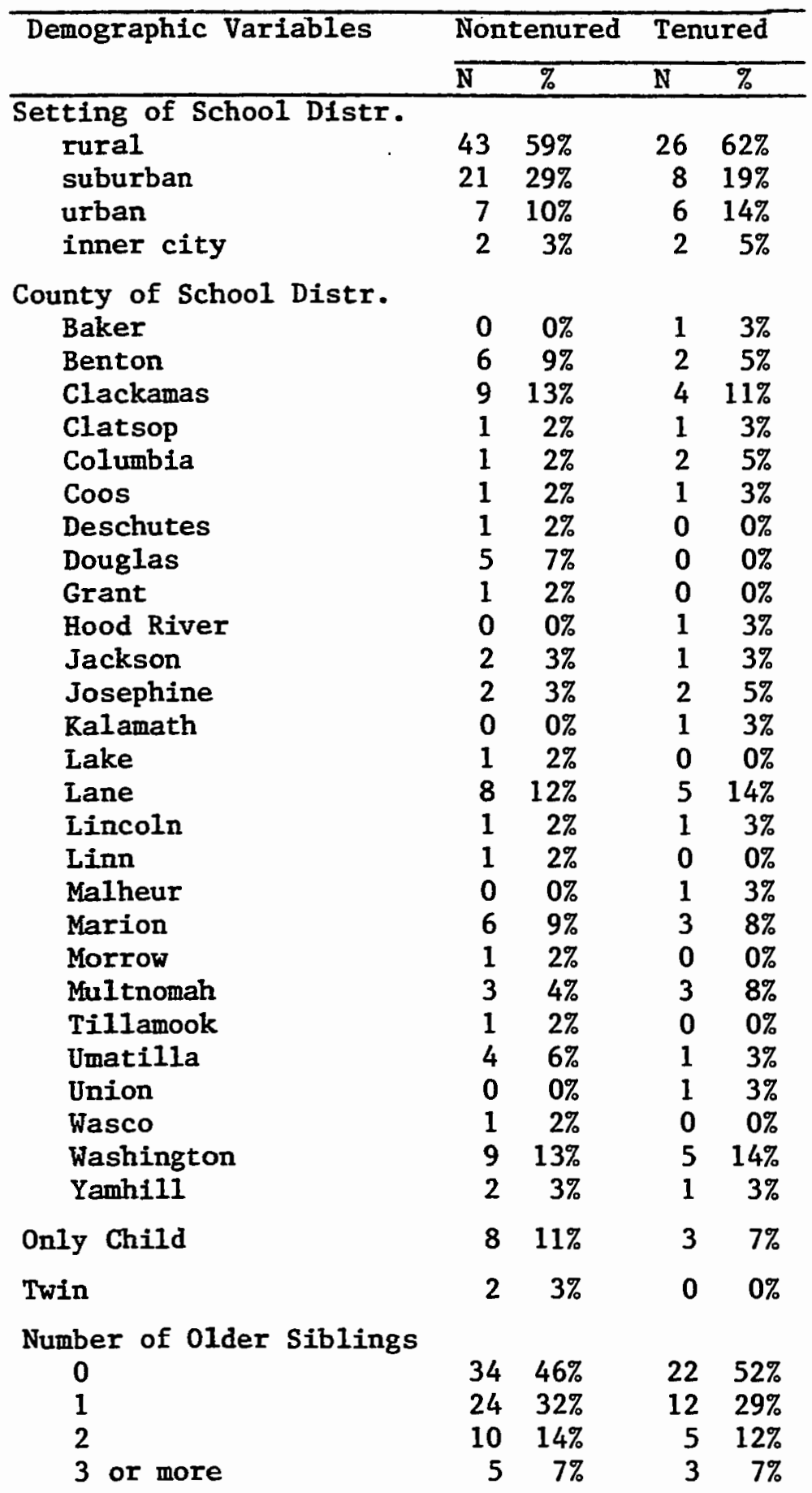


TABLE IX

DEMOGRAPHIC PROFILE OF NONTENURED AND

TENURED FEMALE ADMINISTRATORS

(continued)

\begin{tabular}{|c|c|c|c|c|}
\hline Demographic Variable & Non & tenured & Ten & ured \\
\hline & $\overline{\mathbf{N}}$ & $\%$ & $\mathrm{~N}$ & $\%$ \\
\hline Religion & & & & \\
\hline Protestant & 54 & $73 \%$ & 28 & $.67 \%$ \\
\hline Catholic & 14 & $19 \%$ & 5 & $12 \%$ \\
\hline Jewish & 0 & $0 \%$ & 3 & $7 \%$ \\
\hline other & 1 & $1 \%$ & 2 & $5 \%$ \\
\hline none & 5 & $7 \%$ & 4 & $10 \%$ \\
\hline Ethnicity & & & & \\
\hline White & 68 & $93 \%$ & 39 & $93 \%$ \\
\hline Black & 0 & $0 \%$ & 1 & $2 \%$ \\
\hline Asian & 3 & $4 \%$ & 1 & $2 \%$ \\
\hline Hispanic & 2 & $3 \%$ & 1 & $2 \%$ \\
\hline Educationa Level & & & & \\
\hline bachelors degree & 1 & $1 \%$ & 1 & $2 \%$ \\
\hline masters degree & 67 & $91 \%$ & 34 & $81 \%$ \\
\hline $\mathrm{PhD}$ & 6 & $8 \%$ & 7 & $17 \%$ \\
\hline Rejected for Admin Job & 50 & $67 \%$ & 31 & $74 \%$ \\
\hline Current Salary & & & & \\
\hline Less than $\$ 35,000$ & 22 & $30 \%$ & 3 & $7 \%$ \\
\hline$\$ 35-40,000$ & 24 & $32 \%$ & 9 & $21 \%$ \\
\hline$\$ 40-45,000$ & 17 & $23 \%$ & 16 & $38 \%$ \\
\hline$\$ 45-50,000$ & 9 & $12 \%$ & 10 & $24 \%$ \\
\hline More than $\$ 50,000$ & 2 & $3 \%$ & 4 & $10 \%$ \\
\hline Career Path & & & & \\
\hline elem to middle school & 2 & $3 \%$ & 0 & $0 \%$ \\
\hline elem to high school & 1 & $1 \%$ & 1 & $3 \%$ \\
\hline middle to high school & 2 & $3 \%$ & 1 & $3 \%$ \\
\hline middle to elem school & 2 & $3 \%$ & 3 & $8 \%$ \\
\hline high to middle school & 1 & $1 \%$ & 3 & $8 \%$ \\
\hline high to elem school & 0 & $0 \%$ & 1 & $3 \%$ \\
\hline elem to district off & 2 & $3 \%$ & 5 & $14 \%$ \\
\hline secondary to dist off & 2 & $3 \%$ & 4 & $11 \%$ \\
\hline district off to elem & 4 & $6 \%$ & 3 & $\mathbf{8 \%}$ \\
\hline district off to high & 1 & $1 \%$ & 1 & $3 \%$ \\
\hline no change & 51 & $75 \%$ & 14 & $38 \%$ \\
\hline
\end{tabular}




\begin{abstract}
CHAPTER V
SUMMARY, DISCUSSION, AND RECOMMENDATIONS
\end{abstract}

\title{
INIRODUCTION
}

The following discussion, conclusions and recommendations are based upon analysis of questionnaires, interviews and literature regarding the perceptions and profiles of Oregon women school adninistrators.

A main feature of the study was to find the perceptions of Oregon school administrators to the lists of positive and negative factors that have influenced their careers. The lists of factors were created as an outcome of an American Association of School Administrators (AASA) study conducted by Jones and Montenegro and published in 1982, as Climbing the Career Ladder. This study involved the perceptions of positive and negative factors that women, selected as superintendents, believed had influenced their careers. A questionnaire was administered to all Oregon women adninistrators to determine first, whether the action would still be perceived as important, and secondly to determine whether, when the two groups, aspiring and successful adninistrators, were compared, would there be significant differences in the factors the groups would identify as influential or important. 
SUMMARY

The data indicated that Oregon women generally agreed with the results of the Jones and Montenegro study of 1982. Although there were slight differences in the mean scores for most of the positive influences of their careers. Both groups of women adninistrators, had no opinion about several factors. The factors that were identified for which the acministrators had no opinion were: the influence of their mother's career; their marital status; previous teaching level; the influences of affirmative action; flexible work schedules; the equal distribution of work between men and women; and participation in an assessment center.

The negative factors tested in this study produced similar results to the positive factors. Most of the women agreed or strongly agreed with the identified negative factors. One factor, the unequal distribution of work assigned between sexes, was shown to be significant at $P<.005$ between the groups. Disagreement was not expressed for any factor by either group, but both groups expressed no opinion about their age, affirmative action, male co-worker support, female co-worker support and the use of an assessment center.

A critical element of the study, beyond the identification of influential factors, was the development of a profile for the aspiring and the successful female Oregon school administrator.

An overriding interest in this study was the underrepresentation of women in public education administrative positions in Oregon. The background and interests, positive or negative, of Oregon women should add to the body of knowledge, research, and the comparative study of 
profiles of women in acministration. It is hoped that this study can help provide a more complete picture of the underrepresentation of women in educational administration and its effect on them.

The review of literature documented the domination of education adninistration by men and described many factors that have been attributed to the repression of women from acministrative roles. Cultural norms and socialization (role) expectations placed upon women discouraged them from seeking management positions. The literature also documented discrimination by gender. It was not until Title IV of the Educational Amendments of 1972 and Title II of the Vocational Amendments of 1976 that prohibition of discrimination by gender was convincingly included in legislation and spelled out. Programs since that time have encouraged women to achieve administrative positions, but have shown only limited success.

Underrepresentation of women in administrative work has also been attributed to theories involving the attitudes of the worren themselves and attitudes of males in superior positions. These attitudes concerned the role of women in the family, managerial problen solving, educational experience and the use of networking as a partial solution to underrepresentation of women in educational adninistration. Motivation and role modeling are also discussed in the literature as necessary for the probability of success in an adninistrative career. Most interesting, however, is the fact that what is good for women to do is also good for men when preparing for upward nobility. Two areas stand out as major roablocks for women: (a) women are socialized to a lesser position, i.e. teach, but not adninistrate, and (b) since most education administrators are males, the future of males as 
administrators is easier due to built-in role models. Literature and data results indicate, however, that future professional females need to have appropriate career role models (not necessarily male) like those found in the male population.

Although the literature identified fewer positive influences of upwand mobility for women, most women indicated in this study that they did not feel that the men that had been influential in their careers had been a negative influence.

There is a rich literature indicating that men and women in educational administration have neither a shared history nor identical experiences. The effective woman does not copy the effective man, neither does she find that what works for him necessarily works for her. Rosaldo and Lamphere were quoted in Shakeshaft (1987) as saying, "We must integrate an interest in women into a general theory of society and culture."

\section{THE INSTRUMENTATION}

The instrumentation for this study was designed using the identified factors of upward mobility found in a study conducted in 1982 by Jones and Montenegro of AASA. Using the factors they identified and verified as having an influence on upward career mability for superintendent level administrators, this researcher developed a questionnaire that contained the identified factors and administered the instrument to aspiring and successful female administrators in Oregon. The intent was to compare the groups, prepare a profile of the tenured and nontenured adninistrator and 
hopefully enable aspring women to make career decisions based on those of successful women in school adninistration.

From the instrumentation, it is important to note that nontenured and tenured worren in educational acministration identified separately and as a whole four personal characteristics in the same order: "qualifications", (2) "acministrative experience", (3) "knowledge of the job", and (4) "education". Other characteristics most frequently cited were "hardworking", "likes challenges", and a "strong leader, role model (mentor)".

\section{DISCUSSION}

The steady increase of women adninistrators, even though small, suggests women can secure administrative positions in education. Legal changes regarding employment practices and discrimination of females has helped. Measures to increase self-confidence, encouragement about career aspirations, and role modeling have been factors in the increased numbers of women in higher level educational positions. An increase in the number of women in adninistration has also been due to the changing flow of financial resources from colleges to female students in the form of grants and scholarships. Flexible work schedules and the need to support single parent families or the changing family structure have also been cited as additional reasons for change. Most important, however, is the approval from family, friends and society for women to have career aspirations, better salaries, decision making opportunities and administrative positions. The attitude change toward acceptance of women is essential for a further increase in numbers. Role modeling and 
mentoring for females aspiring to higher than entry level positions in education is now more possible due to the steady, but small, increase in women acininistrators. This, combined with the previously described personal characteristics and personal preparation, should provide a better chance at success.

But, even with social changes, have all the vestiges of discrimination been eliminated? According to the respondents of this study, several barriers to upward mobility still exist.

Within both groups, the majority felt that gender typing of occupations still exists and continues as it did in 1982 when (Jones \& Montenegro) found it to be a leading cause of discrimination among the negative factors in the study. Other factors cited as having a major negative impact were: inadequate recruiting, inadequate support groups, hiring practices, and family obligations. Although advances have been made, even in these areas, it still appears that there are hurdles to overcome if you are a woman and aspire to be a school adninistrator.

Although the situation has improved, it appears that the positive and negative factors for upward mobility for female educators have not changed and are still problems. As one male personnel administrator said, "Two-hundred years of male attitudes cannot be changed in the last twenty years of legislation, policy, or practice."

One thing we do know about women in educational administrative positions is that they have planned for their career. Sixty-five percent of the female principals decided on education as a career in high school and eighty-five percent reported that teaching was their first choice for a career. Men in education chose teaching as a 
career only 278 of the time as high school students and only 468 of the time chose education as their primary occupation. These figures from Gross and Trask (1976) clearly indicate that education is a major interest for wormen.

\section{RECOMMENDATIONS AND IMPLICATIONS}

The results of this study have implications for women and men as educational leaders and policy making bodies in education. The impact of procedures, practices, policies and attitudes has a definite effect on female adninistrators. The results of the study and review of literature clearly show a slow trend toward females being employed in greater numbers. The trend is encouraging, but the strong suggestion of literature still shows that the inequities of gender contribute to low representation of women in administration. Male leadership will take time to change, but clearly women can have a significant impact on educational aconinistration.

The results of this study yield the following implication for the study of women in education acministration:

1) It appears that many barriers come from external sources, such as the lack of role models (female), the "good old boy" network to promote opportunity, influencial sponsors, and the fact that women are often "left out" when job opportunities exist.

2) There is a need for early identification of women with potential for leadership. Counseling about occupational choices should be considered early in the educational career.

3) There is a need for university programs to provide leadership with sponsors and mentor programs for adninistrator development 
and training situations.

4) Despite the limited opportunities for women in educational administration, they must stay prepared. . . work for the administrative certificates, attend assessment centers, be involved with influential others, and avail themselves when positions become available.

5) For leaders in the education profession, it is important to know that discriminatory selection and hiring practices do and have occurred because men have dominated that process. It is equally important to know that women are more than adequately trained with skills and abilities to perform the responsibilities and duties of an adninistrator. Leaders should strive to understand the impact of underrepresentation of women in the profession. The adherence to affirmative action and the evaluation of hiring practices for evidences of discrimination should be undertaken or more closely monitored.

6) For all of education there needs to be recognition that we will all be better off when we choose the best person for the position. Recommendations from this study for women in education adninistration are as follows:

1) Women students should intern with women administrators whenever possible.

2) For boards of education and selection cormittees, again mostly dominated by men, it is important that they monitor at the policy level the affirmative action and career counseling procedures that involve women in the workforce.

3) One observation about the influence of any group or organization 
in history is that it is remembered by how well it is documented. The documentation of women in education's history is sketchy, narrow in its focus, and limited to recent documentation. Women and educational organizations must document their influence and work through organized networks and professional publications. Anything less than a comitment by women in the profession to document their work and exude their influence will result in an educational history that shows a biased male influence. To eliminate the barriers women must work to change the androcentric nature of the culture in which they wish to work. "To do this," suggests Shakeshaft (1982), "Behavioral changes in men and women, structural and legal changes in school and society, and attitudinal changes in everyone must be achieved. No one strategy can be used - many must be used to accomplish this revolution." (p. 126).

4) It is recommended that theory and research need to be restructured and reconceptualized to better include women. Until this is done we are writing a history and practice about men in education adninistration.

5) A specific recommendation is for the development training programs. Courses should be expanded to include women's experiences in administration as an integrated part of the course and not a separate course. Professional organizations, like the National Association of Elementary School Principals (NAESP), the National Association of Secondary School Principals (NASSP), the American Association of School Administrators (AASA), and the National School Boards Association (NSBA) should be requested by 
universities and districts to prepare curricular aids that inoorporate the female world of education.

6) It is recommended that women document their history. Through the use of case studies and historical accounts of women administrators we should be able to develope programs and use female experiences to compare with the male experience.

7) It is recomended that women speakers should be brought into the classroom and on campus to discuss relevant issues of female administration to female students aspiring toward a career in education administration.

\section{SUGGESTIONS FOR FUTURE RESEARCH}

1) The systematic exploration of career paths, leadership skills, and risk taking skills of women in educational adninistration needs to be explored. Research in this area could be done in a study using equal groups of males and females presently working as administrators.

2) Research on the hiring practices of male vs female daninated adninistrations or school boards should be conducted with a focus on the application patterns of women, the demographic background of the districts hiring women and the composition of boards of education.

3) Atudy of male administrators with and without children should be conducted to determine what the effect is on their professional performance.

4) Study the networks that are available to women aspiring toward 
upward mobility.

5) Conduct research, geographically across the nation, to test specific ways to foster upward mobility in administration for women.

6) There should be formal studies done to determine how to open channels for mobility for women at the school district, professional organization, and institutional level. For women to achieve upward mobility, a significant relationship exists between the strategies used in personal life, such as developing a more positive self-oncept, setting career goals, attending training seminars and improving and documenting professional image.

7) Study the experiences of women that have been added to university faculties in educational adninistration to see what relationship and experience exists with those to whan they are teaching about school administration.

8) Research on the styles of women administrators should be supported and encouraged. Workshops should be undertaken at the university level in an effort to incorporate research and experiences of women into course materials.

9) In summary, research must be undertaken that reflects the presence of females and the female world. Only then will we be able to determine whether or not there are differences and, if so, whether they have any real meaning. 
REFERENACES

Abrams, J. D. (1978). From one who made it: Advice to women on their way up in school administration. American School Board Journal, 165(7), 27-28.

Adams, J. (1979, October). Women, success and men. Glamour, 77, 60.

Adkison, J. (1981). Women in school administraton: A review of the research. Review of Educational Research, 51(3), 311-343.

American Association of School Administrators. (1988, August). Women and minorities in school administration. Wash. D.C.: Author.

Anderson, M. E. (1988, May). Hiring princincipals: How school districts recruit, groom, and select the best candidates. Oregon School Study council.

Apple, M. (1983). Work, gender and teaching. Teachers College Record 84(3), 611-628.

Applebaum, E. (1981). Back to work: Determinants of women successful re-entry. Boston: Auburn House.

Bach, L. (1976). Of women: School administration and discipline. Phi Delta Kappan, 57, 463-466.

Barnes, T. (1976). America's forgotten minority: Women school adninistrators. National Association of Secondary School Principals Bulletin, 60(399), 87-93.

Barter, A. S. (1959, Spring). The status of women in school administration - Where will they go fran here? Eoucational Horizons, pp. 72-75.

Biklen, S. K. (1984). Teaching as an occupation for wornen: A case study of an elementary school. NIE Grant G-81-007, unpublished paper. Syracuse, New York.

Biklen, S.K. \& Brannigan, M.B. (1980). Women and educational leadership. Lexington, MA: D.C. Heath and Company.

Biklen, S., \& Shakeshaft C. (1985). The new scholarship on women in handbook for achieving sex equity through education (pp. 44-52). Baltimore, MD: John Hopkins University Press. 
Biklen, Shulman, L.. \& Sykes, G。 (Eds.). (1983). Handbook of Teaching and Policy. New York: Longman.

Bogdan, J. (1980). The transition from parenting to working and parenting. In S. K. Biklen and M. B. Brannigan (Eds.), Women and educational leadership (pp. 209-221). Lexington, MA: D. C. Heath \& Company.

Bogdan, R., \& Biklen S. (1982). Qualitative research for education. Boston: Allyn and Bacon.

Breyer, C.A. \& Zalupski, V. (1981). homen in management: Two points of view, meeting the system. Community and Junior college Journal, 52(2), 11-13.

Clement, J.P. (1975). Sex bias in school leadership. Evanston, IL: Integrated Education Associates.

Climbing the ladder. (1982). School Administrator, 39(7), 24.

Cochran, J. (1978). How do women administrators view job satisfaction and discrimination? Journal of the National Association for Women Deans, Administrators and Counselors, 41(2), 67-68.

Covel, J. \& Ortiz, F. (1978, Fall). Career patterns among school adninistrators. Educational Research quarterly, 4(3), 33-43.

Darley, A. (1976). Big-time careers for the little woman: A dual-role dilemma. Journal of Social Issues, 32(3), 85-97.

Dickson, K. (1987). Oregon Assessment Center: Its influence on candidates' career opportunities and professional development. doctoral dissertation, University of Oregon.

Dole, C. T. (1973, Nov.). Women are still missing persons in administrative and supervisory jobs. Educational Leadership, 31(2), 123-127.

Dorr, R. (1972). Education and women's rights: What the law now says. American Education, 8, 4-10.

Duke, D. (1984). Teaching: The imperiled profession. Albany: State University of New York Press.

Ellenburg, F.C. (1975, winter). Elementary teachers: Male or female? Journal of Teacher Education, pp. 329-334.

Epstein, C.F. (1976). Sex role stereotyping, occupation, and social exchange. Women's Studies 3, 185-194. 
Epstein, C.F. (1971). Woman's place: Options and limits in professional careers. Los Angeles, CA: University California.

Equal Employment Opportunity Commission Office of Research. (1976). Employment Opportunities. Washington, D.C.: Office of Planning Research and Systems.

Equal Employment Opportunity Commission Research Report. (1970, 1973, 1974, 1979, 1980, 1981). Employment opportunities in the schools: Job patterns of minorities and women in public elementary and secondary schools. Washington, D.C.: Office of Planning Research and Systems.

Erickson, K.A., \& Pitner, N.J. (1980). The mentor concept is alive and well. National Association of Secondary School Principals Bulletin, 64(440), 6-13.

Estimates of school statistics. (1981-82). S. Carmon and P. Veittelle. (Eds.). Washington, D.C.: National Education Association.

Estler, S.E. (1975). Homen as leaders in public education. Signs, 1 , 363-380.

Faunce, P. S. (1977). Psychological barriers to occupational success for women. Journal of the National Association for Women Deans, Administrators and Counselors, 40(4), 140-144.

Feistrizer, C. E. Profile of women administrators in the US. Washington, D.C.: National Center for Educational Information, 1988.

Feuers, S. (1978-79). Women in management: Two points of view: shortening the odds. Community and Junior College Journal 52(2), 10-12.

Feuers, S. \& Diamond, D. (1978-79). Husband as mentor: You can do it! An interview with Stelle Feuers. Educational Horizons, 57(2), 90-96.

Feuers, S. (1981). Women in management: Two points of view: Shortening the odds. Community and Junior College Journal, 52(2), 10-12.

Ford Foundation workshops help women administrators seeking superintendencies. (1977). School Administrator, 34(7), 6 .

Frasher, J. M., \& Frasher, R. (1979). Educational administration: A feminine profession. Educational Administration Quarterly, 15. 1-13. 
Freednan, S. (1983). Teaching: An imperiled profession. Handbook of Teaching and Policy (pp. 261-299). New York: Longman.

Futrell, M. H. (1981). Organizing for equal opportunity in ecucation and employment. Educational Horizons, 60(3), 26-29.

Grimm, J. W. \& Stern, R. (1974). Sex roles and internal labor market structures: The "Female" semi-professions," Social Forces, 21, 690-705.

Gross, N., \& Trask, A. (1964). Men and women as elementary school principals. Final Report $\$ 2$, Harvard Graduate School of Eáucation.

Gross, N., \& Trask, A. (1976). The sex factor and the management of schools. New York: Wiley and Sons.

Guy, S.D. (1979). Women and the superintendency: A comparison of female and male career paths and expectations in Ohio. ooctoral dissertation, Kent state University, Ohio.

Hansot, E., \& Tyack D. The Dream Deferred: A golden age for women administrators. Policy Paper No. 81-CI-May 1981. Institute for Research on Educational Finance and Governance, School of Educ., Stanford University.

Henming, R. M. (1981). Women in comunity college administration: A progress report. Unpublished report, Oxnard college, Oxnard, CA.

Henning, M. \& Jardim, JA. (1976). The managerial woman. New York: Pocket Books.

Hines, E.M. (1985). Women in public school administration: A study of the present status of female educators and peroeived factors impacting upward mobility into top-level adninistrative positions in the state of Delaware. Dissertation Abstracts International. (University Microfilms No. 8508889)

Hoffman, N. (1982). Women's true profession. Westbury, NY: The Feminist Press.

Horner, M. S. (1972). Toward an understanding of achievement-related conflicts in women. Journal of Social Issues, 28(2), 157-175.

Howard, S. (1980). Toward educational equity for females and males: Women in administration and governance. Washington, DC: Women's Educational Equity Act Program of the U.S. Department of Education. 
Howard, S. (1975). Wanted - More women: Why aren't women acoministering our schōls? Arlington, VA: National council of Administrative Women in Eoucation.

Hughes, M. A. (1981). An investigation of the aspiration, attitudes, apprehensions and strategies for success of selected women executives in business, government and education: A case study. Dissertation Abstracts International, 42, 1401A-1402A. (University Microfilms No. 81-22,020).

Jewell, D. (Ed.). (1977). Women and management: An expanding role. Georgia State University: Publishing Services Division.

Johnson, J. (1989). With a little help from my friends. Nations Business, $77(1)$. Wash. D.C.: U.S. Chamber of Comerce.

Jones, E., \& Montenegro X. P. (1982). Recent trends in the representation of women and minorities in school acministration and problems of documentation. Arlington, VA: American Association of school Administrators.

Jones, E. H. (1981). Aware network is growing. School Administrator, 38(9), 8.

Jones, E. H. (1980). Bridges to equity. School Administrator, 37(11), 8 .

Jones, E. H. (1983). Update on women and minority superintendents. School Adninistrator, 40(6-7), 17.

Jones, E. H. \& Montenegro, X. P. (1982a). Climbing the career ladder: A research study of women in school actininistration. Arlington, VA: American Association of School Administrators.

Kaufman, P. (1984). Woman teachers on the Frontier. New Haven: Yale University Press.

Kanter, R. (1977). Men and women of the corporation. New York: Basic Books.

Lather, P. (1984, June). Gender and the shaping of public school teaching: Do good girls make good teachers? Paper presented at the National Women Studies Association Conference.

Lautzenheiser, B. J., (1977). Are you willing to pay the price? Business Education Forum, 31(7), 23-27.

Lerner, G. (1979). The majority finds its past. New York: Oxford University Press. 
Lightfoot, S. (1983). The lives of teachers. Handbook of Teaching and Policy. (pp. 241-260). New York: Longman.

Loposer, N. (1979). Career mobility for women in educational administration. Unpublished paper. Auburn, Alabama: Auburn University.

Lovelady, F. D. (1980). Wamen and minorities in the principalship: Career opportunities and problems. National Association of Secondary School Principals Bulletin, 64(440), 18-28.

Luckett, R., Underwood, K.E., and Fortune, J.C. (1987). Men and women, just how different are they? American School Board Journal, 173(1). Wash. D.C.: National School Boards Association.

Lyon, C. D., \& Saario, T. N. (1973, October). Women in public education: sexual discrimination in promotion. Phi Delta Kappan, 54, 120-123.

McCarthy, M., \& Zent. A. (1982). Afficmative action for school administrators: Has it worked, can it survive? Phi Delta Kappan, 63, 46I-463.

McPheron, L., \& Smith, J. K. (1981). Women administrators in historical perspective; Toward an androgynous theory of leadership. Educational Horizons, 60(3), 22-25.

Melder, K. (1977). Beginnings of sisterhood. New York: Schocken Books.

Men vs women. (1988, August 8). U.S. NewS, 105(6), 50-57.

Morsink, H.M. (1969). Leader behavior of men and women secondary school principals. Washington, D.C.: National Council of Administrative homen in Education.

Morsink, H. M. (1970). Leader behavior of men and women principals. National Association of Secondary School Principals Bulletin, 54(347), 80-87.

National Association of Elementary School Principals. (1981). A statistical report. Arlington, VA: Author.

National Education Association. (1971). 25th biennial salary survey of public professional personnel 1970-71 (Research Report 1971-R51. Washington, D. C.: Author, Research Division. 
National Education Association Report. (1983). Education 1983: aur year in review. Portrait of a teacher; Teacher pay: ToO low, too long: Education pays; More vidiocy; More women work for less. Washington, D.C.: National Ecucation Association.

National Education Association Research Divisicn. (1972-73, 76). 26th biennial salary and staff survey of public school professional personnel. Washington, D.C.: National Education Association.

Nelton, S. (1988). Meet your new work force. Nations Business, 76(7), 14-21. Wash. D.C., U.S. Chamber of Commerce.

Nelton, S. (1989). The age of the woman entrepreneur. Nations Business, 77(5), 22-30. Wash. D.C.: U.S. Chamber of Commerce.

Newman, I. (1976). Basic procedures in conducting survey research. Akron, OH: The University of Akron.

Nie, N. H., \& Hull, C. H. (1981). SPSS combined edition. New York: MoGraw-Hill (statistical package for the social sciences).

Ohles, J. (Ed.). (1978). Biographical directory of American educators. Westport, CF: Greenwood Press.

Oregon School Directory (1988). Salem, OR: Oregon Department of Education.

Ortiz, F. I., (1981). Career patterns in education: Men, women and minorities in public school acministration. New York: Praeger.

Ortiz, F. I. (1982). The distribution of Mexican-American women in school organization. Hispanic Journal of Behavioral Sciences, 4(2), 181-198.

Pacheco, B. A. (1982). Barriers to advancement in educational administration as perceived by women administrators. Dissertation Abstracts International, 43, 1377A. (University Microfilms No. 82-83, 921).

Pavlicko, M.A. (1985). Women in Educational administration in the state of Ohio: Factors relating to upward career mobility. (University Microfilms International, No. 8514705)

Peters, J. (1980). The quest of the new woman in public school education: 1980. National Association of Secondary School Principals Bulletin, 64(440), 14-18. 
Pfiffner, V.T. (1976). Composite profile of a top-level California community college woman administrator. Journal of the NAWDAC, 40(1), 103.

Pharis, B. (1979). Why not the best? National Elementary Principal, 59, 93.

Picker, A. M. (1980). Female educational administrators: coping in a basically male environment. Educational Horizons, 58(2), 149.

Poll finds minorities likely to leave teaching. (1988, Oct. 31). AASA Leadership NewS, p. 4.

Rogers, H.C. (1988). Rogers' rules for business $=$ women. New York: St. Martins Press.

Rometo, L. K. (1983). Women aoministrators in Permsylvania's public schools. Dissertation Abstracts International, 44, 0036A. (University Microfilms No. 83-11, 564).

Rosser, P. (1980, March). Women fight "old boys" for school acministrators jobs. Learning, Pp. 31-34.

Sanchez, V. V. (1984). Factors affecting the selection of female verses male public school superintendents. (University Microfilms International No. 8504757)

Sandorff, P. (1980). Women administrators in public education: Eactors for successful entry. (Doctoral dissertation, Claremont Graduate Scho1, 1980).

Schmuck, P. A. (1980). Changing women's representation in school management: A systems perspective. In S. K. Biklen \& M. B. Branningan (Eds.), Women and educational leadership (pp. 239-259). Lexington, MA: D. C. Heath \& Company.

Schmuck, P. A. (1975). Sex differentiation in public school administration-"Wanted: More Women" series(report No. RIE DEC 76). Washington, D.C.: National Council of Administrative Wanen in Education. (ERIC Document Reproduction Service NO. ED 126 593).

Schmuck, P. (1980). Sex equity in educational leadership: The Oregon story. Newton, Mass: Education Development Corporation.

Schmuck, P. A. (1976, October). The spirit of Title IX: Men's work and wamen's work in Oregon public schools. Oregon school Study council, 20(2).

Schmuck, P.A. (Ed.). (1987). Women educators: Employers of schools western countries. New York: State University Press. 
Schmuck, P., Charters Jr., W. W., \& Carlson, R. (Eds.). (1981). Sex equity in education. New York: Harcourt Brace.

Schmuck, P., et al. (1985). Administrative strategies for institutionalizing sex equity in education through education. Sex Equity Through Education in Sex Equity Through Education. Klein, Susan (Ed.). Baltimore, John Hopkins Press.

Schmuck, P., \& Wyant, S. (1981). Clues to sex bias in the selection of school administrators. In Educational Policy and Management: Sex Differentials. New York: Academic Press.

Schmuck, R., \& Runkel, P. J. (1985). Third handbook of organized develogment in schools. Palo Alto, CA: Mayfield Press.

Shakeshaft, C. (1985). Strategies for overcoming the barriers to women in educational administration. In S. Klein (Ed.), Handbook for achieving sex equity through education (pp. 124-144). John Hopkins University Press.

Shakeshaft, C. (1987). Women in educational adninistration. Newbury Park, CA: Sage Publications.

Shakeshaft, C. (1981). Women in educational acministration: A descriptive analysis of dissertation research and paradigm for future research. In Schmuck, Charters, \& Carlson (Eds.), Educational policy and management: Sex Differentials. New York: Academic Press.

Shakeshaft, C. (1982). Women's true profession: A teaching quide. hestbury, N.Y.: The Feminist Press.

Shakeshaft, C., \& Nowell, I. (1984). Research on theories, concepts, and models of organizational behavior: The influence of gender. Issues in Education, 2(3), 186-203.

Shulman, L., \& Sykes, G. (Eds.) (1983). Hanobook of teaching and policy. New York: Langman.

Simmons, A., Freedinan, A., Dunkle, M. J., \& Blau, E. (1975). Exploitation from 9 to 5 . Lexington, MA.

Staff. (1987). Female Executive, 8(3), 11-12.

Status of Women AASA members: Women in administration. (1982). School Administrator, 39(8), 34-35.

Stewart, N. (1978). The effective woman manager, NY: Willey \& Sons. 
Stewart, A.J., Lykes, M.B., \& LaFrance, M. (1982). Echucated women's career pattems: Separating social and developmental changes. Journal of Social Issues, 38(1), 97-117.

Stockard, J. (1979). Public prejudice against women school administrators: The possibility of change. Educational Administration quarterly, 15, 83-96.

Stockard, J. (1980). Sex equity in ecucational leadership. An analysis of a planned social change project. Newton, MA: Educational Development Corporation.

Stockard, J., et al. (1980). Sex equity in education. New York: Academic Press.

Stockard, J., \& Kempner, R. (1981). Women's representation in school administration: Recent trends. Educational Adninistration quarterly, 17(2), 81-91.

Stockard J., Schmuck, P., Kempner, K., \& Williams, P. (1980). Sex equity in education. New York: Harcourt Brace.

Strober, M. H. (1988, April). The processes of occupational segregation: Relative attractiveness and patriarchy. Paper presented at New Orleans, LA.

Strober, M. \& Arnold, C. J. (1987). The dynamics of occupational segregation among bank tellers. In Brown, Clair, \& J. Pechman (Eds.), Gender in the workplace. Washington D.C.: The Brookings Institution.

Strober, M.H. \& Tyack, D. (1980). Why do women teach and men manage? A report on research on schools. Signs, 5, 494-503.

Survey: Attitudes toward women as school district administrators (1981). ArIington, WA: Educational Research Services.

Taylor, R.R. (1988). Exceptional entrepreneurial woman: Strategies for success. hestport, CT: Greenwood Press.

Taylor, R. R. (1989). How women succeed as entrepreneurs. Nations Business, 77(7), 50-51. Wash. D.C.: U.S. Chamber of Commerce.

Terborg, J. R. (1977). Women in management: A research review. Journal of Applied Psychology, 62, 647-664.

Tetreault, M. K. (1985). Eeminist phase theory: An experiencederived evaluation model. Journal of Higher Education, 56(4), 364-384. 
Tetreault, M. K., \& Schmuck, P. (1985). Equity, educational reform and gender. Issues in Education, 3(1), 45-67.

Tevis, M. (1981). The status of women: The path toward legal personhood. Educational Horizons, 60(3), 11-14.

Thompson, H.G. (1987). Oregon women: A report on their education, employment and economic status. Sälem, OR: Oregon Department of Ecucation.

Tyack, D. B. (1974). The one best system. Cambridge, MA: Harvard University Press.

Tyack, D., \& Hansot, E. (1982). Managers of virtue. New York: Basic Books.

Tyack, D.B. \& Strober, M.H. (1981). Jobs and gender: A history of the restructuring of educational employment by sex. In P.A. Schmuck \& W.W. Charters (Eds.), Educational policy and management: Sex differentials. New York: Academic Press.

United States Department of Labor, Bureau of Labor Statistics (1980, December). Washington, D.C.: United States Govemment Printing Office.

Van Meir, E. J. (1975, Summer). Sexual discrimination in school adninistration opportunities. Journal of NAWDAC, pp. 163-167.

Villadsen, A. W., \& Tack, N. W. (1981). Cambining hame and career responsibilities: The methods used by women executives in higher education. Journal of the National Association for Women Deans, Acministrators and Counselors, 45(1), 20-25.

Walker, D. M. (1981). Factors a ffecting the advancement of women within educational administration: Managerial effectiveness, career aspiration, professional socialization and the culture of the organization. Dissertation Abstracts International, 42. 0498A. (University Microfilms No. 81-17, 276)

Weber, M. B. et al. (1980, April). A study of factors affecting career aspirations of women teachers and educational administrators. Paper presented at the annual meeting of the American Educational Research Association, Boston, MA.

Weber, M.B., Eeldman, J.R., \& Poling, E.C. (1981). Why women are underrepresented in educational adninistration. Educational Leadership, 38, 320-322.

Women found gaining in assistant slots. (1988, August 15). AASA Leadership News. 
APPENDIX A

QUESTIONNAIRE MATERIALS 
March 27, 1989

Dear Administrator,

Recent studies indicate that women are clearly under represented in the education profession as admininistrators. Factors impacting upward career mobility for female administrators in education are a concern because there is only speculation as to why the under representation of women in the profession continues to occur at a time when it appears that many women may be qualified.

In an attempt to determine the factors that have impacted the upward mobility of women in educational administration, I would like you to respond to the enclosed questionnaire. This questionnaire is being sent to all female administrators currently identified as members of the Confederation of Oregon School Administrators.

Your candor and promptness in returning the questionnaire is of great importance. I have attempted to define specific factors as defined by current literature that impact upward mobility for female administrators in Oregon. I am requesting that you:

(a) respond to each of the categories;

(b) make any comments about any category or Item that you believe to be unclear or redundant; and

(c) make general comments about the thoroughness of each category.

Please return the questionnaire by Friday, April 7, 1989. Time is a critical element for me to complete this research project.

Sincerely,

Lee Chapman

Mail completed questionnaire to:

Lee Chapman, doctoral candidate

Educational Leadership, Portland State University

65579 E. Alpine Way

Rhododendron, Oregon 97049 
Informed Consent

I, - hereby agree to serve as

a subject in the research project of Leland D. Chapman, entitled Women In Educational Administration In the State of Oregon: Factors Relating to Upward Mobility, conducted under the supervision of Dr. John Lind, Department of . Educational Leadership, Portland State University.

I understand the study is anonymous, but asks sensitive questions about marital status, religion, racial/ethnic background, income, and religion, to be used to create a profile of women school administrators in the state of 0regon.

I understand that the possible risks to me associated with this study might be psychological, or discomforts due to an invasion of privacy or inconvenience due to a demand on my personal or professional time.

It has been explained to me that the purpose of this study is to identify factors of upward career mobility for women in educational administration in Oregon, to create a profile of those factors to enable women seeking administrative positions to succeed, and hopefully, be better represented in the field of school administration.

I may not recelve any direct benefit from participation in this study, but my participation may help increase knowledge, which may benefit others in the future.

Lee Chapman has offered to answer any questions I may have about the study and what is expected of me in this study. I have been assured that all information I give will be kept confidential, and that the identity of all subjects will remain anonymous.

I understand that I am free to withdraw from participation in this study at any time without jeopardizing my relationship with Portland State University. 
I have read and understand the foregoing information.

date

signature

If you experience problems that are the result of your participation In this study, please contact the secretary of the Human Subjects Research and Review Comittee, Office of Grants and Contracts, 305 Cramer Hall, Portland State University, P.0. Box 751, Portland, Oregon 97207, or phone (203) $464-3417$. 
UPHARD MOBIIITY QUESTIONNAIRE

FOR FEMALE EDUCATION ADHINISTRATORS

\section{Directions}

This questionnaire consists of a list of factors that have been Identified as impacting upward mobility of female education administrators. Please circle or write the appropriate number or item in part I.

Example: D. Number of years in present position.

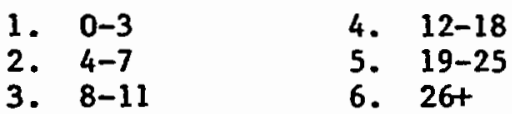

In part II and III please indicate the degree of agreement for the items using a 5-point scale.

Example: 1. Financial resources for formal preparation

$$
\begin{aligned}
& 1 \text { - strongly agree } \\
& 2 \text { - agree } \\
& 3 \text { - disagree } \\
& 4 \text { - strongly disagree } \\
& 5 \text { - no opinion }
\end{aligned}
$$

Please respond to every item.

In part IV please check the appropriate answer from the list. Items I and $J$ are optional, but would be very helpful in creating a profile of the successful female administrator in Oregon's public schools.

Part $\mathbf{V}$ requires that you identify career characteristics by checking all appropriate descriptions.

Part VI Is again a check list of factors that identify your career pattern.

Your responses will be treated confidentially. This researcher will be the only one to see them. It is 1mperative that you consent to be a part of this research. When you have completed the questionnaire, please return it in one of the enclosed stamped, addressed envelopes. To assure your reply is anonymous, return your consent to participate in the second stamped, addressed envelope. Thank you for your cooperation. 


\section{QUESTIONAAIRE .}

ORECON FEMALE EDUCATION ADMINISTRATOR

UPWARD CAREER MOBILITY SURIEY

Please circle or sice your response to the listed items.

PIease make coments or suggestions in the margins regarding clarity, $\log 1 \mathrm{c}$, ambiguity or other items you think should be included.

1. Present position description

A. Position held immediately prior to present position

B. Present employment status

1. Supervisor

2. Coordinator

3. Director (personnel, curriculum, etc.)

4. Assistant principal (K-6) (K-8)

5. Assistant/Associate/Vice-Principal (5-8) (7-12)

6. Principal - elementary

7. Principal - middle school/junior high

8. Principal - high school

9. Administrative assistant

10. Assistant superintendent

11. Superintendent

C. Number of years in present position
i. $0-3$
4. 12-18
2. 4-7
5. 19-25
3. $8-11$
6. $26 t$

D. Number of years in position immediately prior to present position
1. $0-3$
2. $4-7$
4. $12-18$
3. $8-11$
5. 19-25
6. $26+$ 
II. Factors perceived to have a positive impact on female upward mobility for an administrative position in public education.

$$
\begin{array}{ll}
1 \text { - strongly agree } & 3 \text { - disagree } \\
2 \text { - agree } & 4 \text { - strongly disagree }
\end{array}
$$

Factors:

1. Adequate financial resources for formal preparation

2. High aspiration for an administrative position

3. College preparation and appropriate credentials

4. Approval from family and friends

5. Increase job responsibility (power/status)

6. Better salary/better benefits (remuneration)

7. Co-worker/professional organization approval

8. Approval/encouragement from immediate supervisor or other district administrator

9. Career role model (mentor)

10. Opportunity for personal advancement

11. Opportunity for professional advancement (career aspirations)

12. Self confidence/training center involvement

13. Career role model of mother

14. Marital status: never married, married, widowed,

15. Level of teaching: sentor high

16. Effective affirmative action programs/policy

17. Nondiscriminating hiring practices

18. Flexible work schedule

19. Equal distribution of work/activity assignments between men and women

20. Assessment center review

III. Factors having negative impact on career mobility for females in education administration. Again, using the 5-point scale, indicate your degree of agreement with the items.

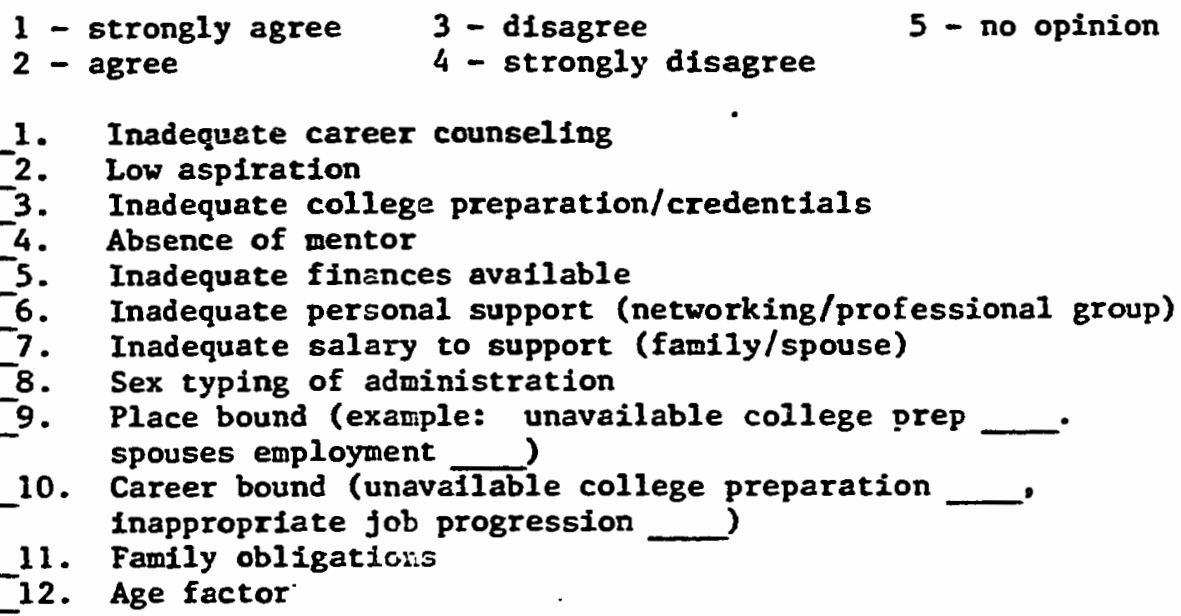


13. Unequal distribution of job related activit ies between men and vomen

14. Lack of any recruiting, selection or hiring program in district

15. Inadequate professional preparation in area of personal marketing

16. Lack of enforcement of affirmative action plan/policy

17. Inapproprlate (discriminating) hiring practices experlenced.

18. Little or no encouragement from male administrators/colleagues

19. Little or no encouragement from female colleagues

20. Use of an assessment center/device where results (when available) may be percelved as limiting.

IV. Background Description

A. Education

Undergraduate School

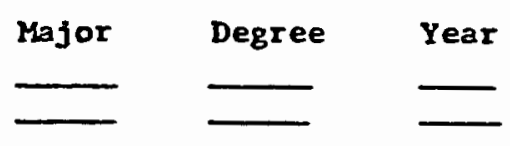

Graduate School

Further Edurat ion

B. Age, cherk appropriate range:
1. 20-30
3. 41-50
4. $51-60$
5. $61+$

c. Current marital stetus:

1. Never married

2. Married

3. Separated

\begin{tabular}{ll} 
4. & Divorced \\
\hline 5. & Widowed \\
6. & Remarried
\end{tabular}

D. If married, educationsl level of tusband:

E. Occupation of husband:

F. Number and ages of children:

1. None
2. One (age __


G. Did your mother work outside the howe when you were growing up? 1. Yes (Major occupation

2. No

3. No mother-figure in home

H. Relationship in family order

1. Number of brothers

2. Number of sisters

3. Your position in order of siblings

4. How many. brothers and/or sisters are older than you?

5. Twin

I. In what religion were you reared?

\begin{tabular}{ll} 
1. & Protestant \\
2 2. & Catholic \\
\hline 3. & Jewish
\end{tabular}

J. What is your racial/ethnic background? (optional)

1. White (not Hispanic)

2. Black (not Hispanic)

3. Asian American/Pacific Islander

4. Ameriran Indian/Alaskan Kative

5. Hispanir.

v. Self-Description Inventcry

The following terms have been used to describe career woren.

1. Place a check besidie those words you consider to be characteristic of you.

\begin{tabular}{l} 
able to keep things \\
in perspective \\
oble to remembs: details \\
adventurous \\
affiliative \\
aggressive \\
ambitious \\
ascertive \\
conforwing, perisps \\
to excess \\
conscientious \\
creative \\
decisive \\
dominating \\
fearful of succsss \\
flexible \\
hardworking \\
imaginative \\
\hline impulsive \\
Inquisitive \\
intellectually :ompetent \\
Introverted \\
objective
\end{tabular}

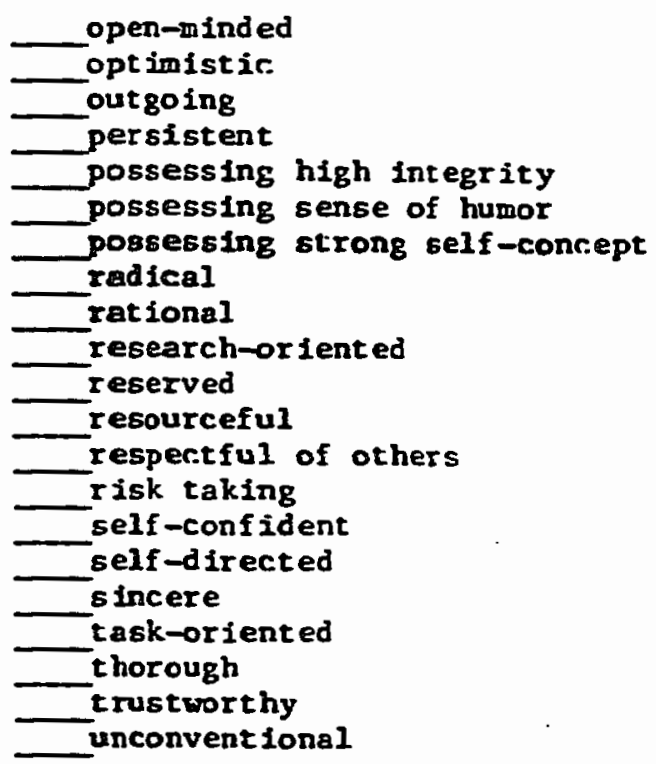


2. Write below other words that describe you if onitted from this 11 st.

3. Please choose a single descriptor (from this list or elsewhere) which you feel most succinctly characterizes your personality/ work-style in relation to your having been selected for your present position.

VI. Career Patterns

A. Have you applied for an administrative position(E) which you did not receive?

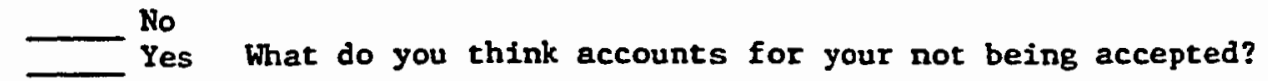

B. Annual income from present position

1. Below $\$ 35,000$

2. $\$ 35,000-\$ 39,999$

3. $\$ 40,000-\$ 44,999$

4. $\$ 45,000-\$ 49,999$

5. $\$ 50,000 t$

c. How have you changed career levels in administration? (Check those that apply.)

1. Elementary to mid/jr. high

2. Elementary to high school

3. mid/jr. high to high school

4. mid/jr. high to elementary

5. high school to mid/jr. high

6. high school to elementary

7. elementary to district office administration

8. secondary to district office administration

9. district office administration to elem. $\mathrm{K}-8$ administration

10. district office administration to high school administiation

11. no change

D. How long did you teach before entering administration?

1. 1-3 years

2. 3-6 years

3. 6-9 years

4. $9-12$ years

5. $12+$ years 
E. If the money were better, would you return to teaching?
1. Yes
2.
No

F. During your career, have you been discriminated against by gender?

1. Yes

2 . No

G. If yes to $F$, how?

1.

2.

3. Personally

Frofesstomal

4. Other (describe)

H. Has the dominance of men in the field of education administration presented you with some professional difficulties?
1. None
2. Very little
3. Moderate
4. Considerable
5. — Extreme

I. Who did you look to as a role model?
1.
2. Female
Comment

J. How do you find the physical setting of your school/district?

1. Rural

2. Suburban

3. Urban

4. Inner city

5. Please name your county

Thank you for completing this questionnaire. It is my hope that through your participation the under representation of women in educational administration can be better understood and ultimately reduced. 
APPENDIX B

NAFE MEMBER SURVEY RESULTS 


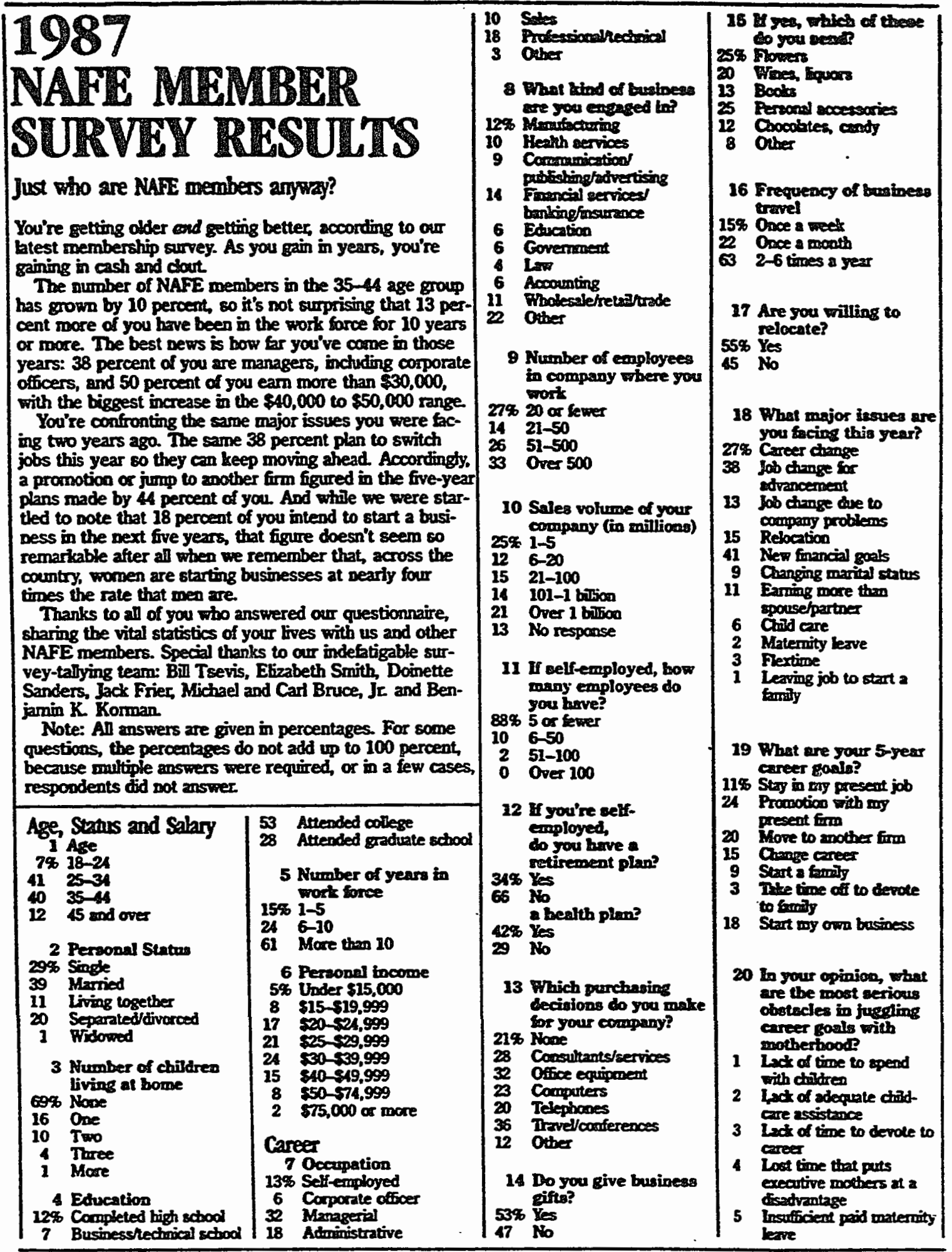

MuYoune 2507 


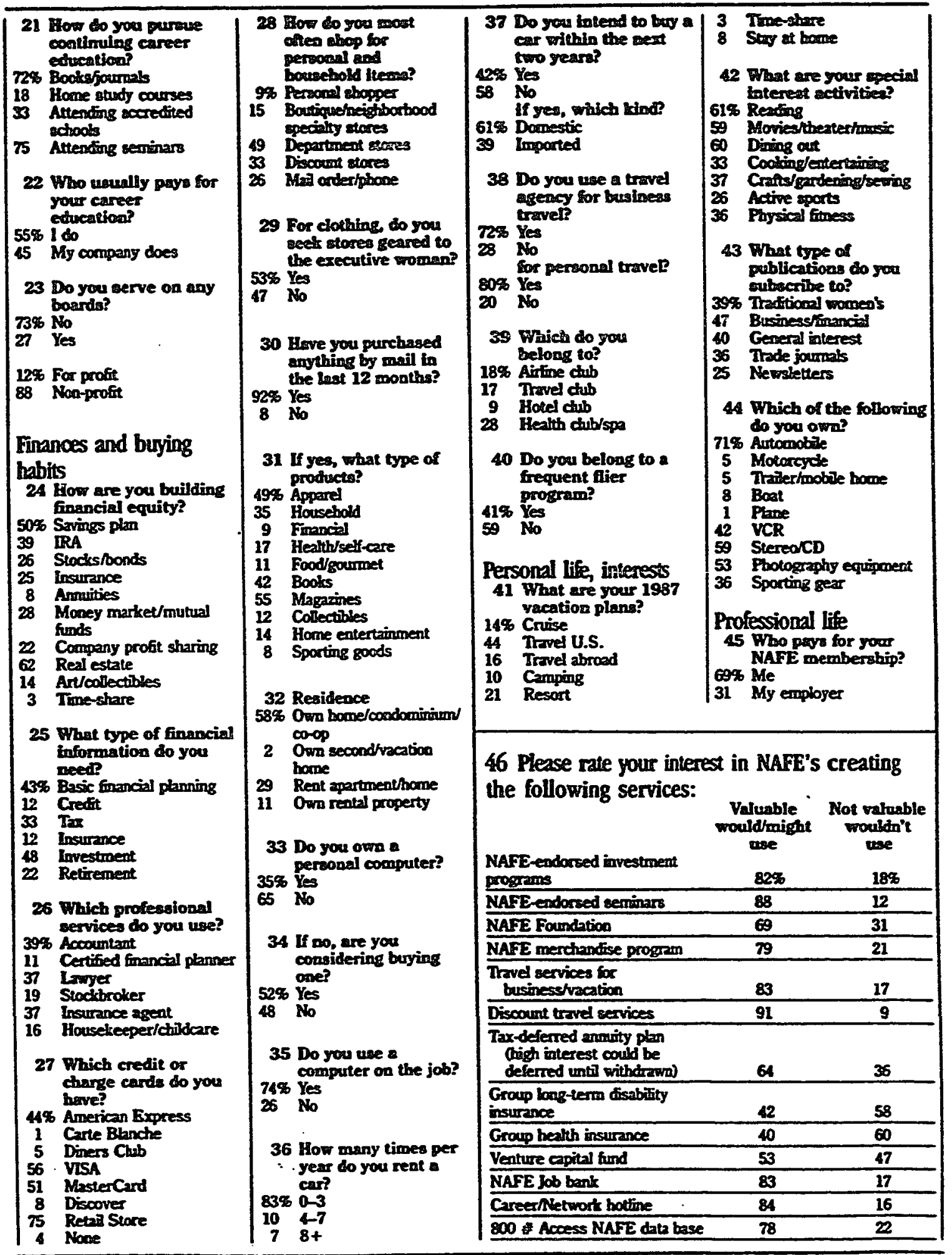

